\title{
WO-monitor economie 1996 : basismeting cohort '95
}

\author{
Citation for published version (APA):
}

Ramaekers, G. W. M. (1997). WO-monitor economie 1996 : basismeting cohort '95. Researchcentrum voor Onderwijs en Arbeidsmarkt, Faculteit der Economische Wetenschappen. ROA Reports No. 4 https://doi.org/10.26481/umarep.1997004

Document status and date:

Published: 01/01/1997

DOI:

10.26481/umarep.1997004

Document Version:

Publisher's PDF, also known as Version of record

\section{Please check the document version of this publication:}

- A submitted manuscript is the version of the article upon submission and before peer-review. There can be important differences between the submitted version and the official published version of record.

People interested in the research are advised to contact the author for the final version of the publication, or visit the DOI to the publisher's website.

- The final author version and the galley proof are versions of the publication after peer review.

- The final published version features the final layout of the paper including the volume, issue and page numbers.

Link to publication

\footnotetext{
General rights rights.

- You may freely distribute the URL identifying the publication in the public portal. please follow below link for the End User Agreement:

www.umlib.nl/taverne-license

Take down policy

If you believe that this document breaches copyright please contact us at:

repository@maastrichtuniversity.nl

providing details and we will investigate your claim.
}

Copyright and moral rights for the publications made accessible in the public portal are retained by the authors and/or other copyright owners and it is a condition of accessing publications that users recognise and abide by the legal requirements associated with these

- Users may download and print one copy of any publication from the public portal for the purpose of private study or research.

- You may not further distribute the material or use it for any profit-making activity or commercial gain

If the publication is distributed under the terms of Article $25 \mathrm{fa}$ of the Dutch Copyright Act, indicated by the "Taverne" license above, 


\section{WO-monitor economie 1996}

\section{Basismeting cohort '95}

ROA-R-1997/4

G.W.M. Ramaekers

\section{Researchcentrum voor Onderwijs en Arbeidsmarkt}

Faculteit der Economische Wetenschappen en Bedrijfskunde Universiteit Maastricht

Maastricht, juni 1997 
ISBN 90-5321-208-6 SEC97.084 


\section{Inhoud}

Bladzijde

Voorwoord i

Samenvatting iii

1 Inleiding 1

1.1 Opzet WO-monitor economie 1

1.2 Samenstelling onderzoekspopulatie 3

2 Intrede op de arbeidsmarkt $\quad 7$

$\begin{array}{ll}2.1 \text { Zoeken naar werk } & 7\end{array}$

2.2 Maatschappelijke positie enquêtemoment 9

3 Baankenmerken 13

3.1 Functieverwerving 13

$\begin{array}{ll}3.2 \text { Typering werk } & 15\end{array}$

$\begin{array}{ll}3.3 \text { Functievereisten } & 19\end{array}$

$\begin{array}{ll}3.4 \text { Arbeidsvoorwaarden } & 21\end{array}$

4 Factoren die de arbeidsmarktpositie beïnvloeden 25

5 Voorbereiding op beroepspraktijk 33

5.1 Vóór het afstuderen opgedane extra kwalificaties 33

$5.2 \mathrm{Na}$ het afstuderen opgedane extra kwalificaties $\quad 35$

$\begin{array}{ll}5.3 \text { Afstemming tussen opleiding en werk } & 37\end{array}$

6 Opleiding achteraf bezien $\quad 45$

6.1 Oordeel over de opleiding $\quad 45$

$\begin{array}{ll}6.2 \text { Studiekeuze achteraf bezien } & 46\end{array}$

7 Thema: Mobiliteit bij de intrede op de arbeidsmarkt 51

$\begin{array}{ll}\text { Bijlage } 1 \text { Verklarende variabelen } & 59\end{array}$ 


\section{Voorwoord}

In opdracht van het College van Bestuur van de Universiteit Maastricht (UM) verricht het Researchcentrum voor Onderwijs en Arbeidsmarkt (ROA), dat verbonden is aan de Faculteit der Economische Wetenschappen en Bedrijfskunde van de UM, vanaf 1990 jaarlijks onderzoek naar de arbeidsmarktpositie en loopbanen van afgestudeerden - waaronder economen - van de UM. Met ingang van 1994 verricht het ROA, in opdracht van de economische faculteiten van de Erasmus Universiteit Rotterdam (EUR) en de Katholieke Universiteit Brabant (KUB), tevens arbeidsmarktonderzoek onder economen die aan de EUR en de KUB zijn afgestudeerd. Vanaf 1996 is dit onderzoek, de WO-monitor economie, uitgebreid met de economische faculteiten van de Universiteit van Amsterdam (UvA) en de Vrije Universiteit (VU).

In het onderzoek wordt een uitgebreid beeld verschaft van de arbeidsmarktintrede van de afgestudeerden. Daarnaast wordt een aantal vragen gesteld waarmee de inhoud van het curriculum in het licht van de beroepsuitoefening kan worden geëvalueerd. In dit rapport worden de resultaten gepresenteerd van de enquête die eind 1996 - begin 1997 heeft plaatsgevonden. Aan deze enquête, hebben in totaal 1556 economen meegewerkt.

Het ROA voert dit project uit in samenwerking met DESAN Marktonderzoek te Amsterdam. Het ROA heeft bij de uitvoering van het onderzoeksproject de leiding en is verantwoordelijk voor de instrumentontwikkeling, de kwaliteitsbewaking, het databeheer alsmede het thans voorliggende, analytisch gerichte eindrapport. DESAN Marktonderzoek is verantwoordelijk voor de gegevensverzameling, de gegevensverwerking en het maken van de vertrouwelijke, statistische faculteitsrapportages ten behoeve van de deelnemende faculteiten.

De projectleiding, alsmede de uitvoering van de analyses en de verslaglegging van het thans voorliggend eindrapport, is in handen van drs. G.W.M. Ramaekers van het ROA. De vertrouwelijke faculteitsrapportages zijn door drs. ing. K.J. Pagrach van DESAN Marktonderzoek opgesteld, terwijl ing. J.J. Rutjes de werkzaamheden van DESAN Marktonderzoek voor het onderzoeksproject coördineert. Vanuit de EUR wordt het project begeleid door drs. N. Twigt, vanuit de KUB door drs. L.E.G.A. Bals, vanuit de UM door drs. I.M. Wijk, vanuit de UvA door drs. P.L. Hilkhuysen en vanuit de economische faculteit van de VU door drs. M. van Esch.

Uiteraard is dank verschuldigd aan de afgestudeerden die de vragenlijst hebben ingevuld.

Maastricht, juni 1997 


\section{Samenvatting}

Eind 1996 - begin 1997 is in het kader van de WO-monitor economie voor de derde keer een arbeidsmarktonderzoek gehouden onder afgestudeerde economen. Aangezien de enquête één tot anderhalf jaar na het afstuderen plaatsvindt, heeft het onderzoek betrekking op economen die nog aan het begin staan van hun beroepsloopbaan. Aan de enquête hebben in totaal 1556 economen meegewerkt, hetgeen neerkomt op een respons van $56 \%$.

\section{Samenstelling onderzoekspopulatie}

Van de onderzoekspopulatie is $6 \%$ afgestudeerd in Bedrijfskunde (BK), $4 \%$ in Bestuurlijke Informatiekunde (BIK), 10\% in Econometrie (Ectrie), $8 \%$ in Algemene Economie ( $A E$ ), 59\% in Bedrijfseconomie (BE), 2\% in Fiscale Economie (FE), eveneens $2 \%$ in Internationaal Management (IM) en $8 \%$ in andere economische opleidingsrichtingen (Ec-overig). De onderzoekspopulatie wordt niet alleen gedomineerd door bedrijfseconomen, maar nog steeds ook door mannen (74\%, vorig meetjaar $76 \%$ en het jaar daarvoor $77 \%$ ). Het aandeel van vrouwelijke economen neemt dus licht toe. De gemiddelde leeftijd op het moment van enquêteren bedraagt 26,5 jaar (bij de vorige meting 26,4 jaar).

\section{Maatschappelijke positie}

De meeste $(87 \%)$ economen zijn na het afstuderen niet of in totaal hooguit drie maanden werkzoekend geweest. Dit is een verbetering ten opzichte van de vorige enquête $(78 \%)$ en de daaraan voorafgaande meting (72\%). Afgestudeerde economen vinden dus steeds sneller werk. Jongere afgestudeerden blijken sneller werk te vinden dan ouderen, en vrouwelijke afgestudeerde vinden sneller werk dan mannelijke afgestudeerden. Ook afgestudeerden die beschikken over extra kwalificaties, bijvoorbeeld in de vorm van voor het vakgebied relevante werkervaring en bestuurlijke ervaring, vinden sneller een baan. Vergeleken met algemeen economen (de referentiegroep in de analyse) vinden bedrijfskundigen en econometristen sneller werk.

Op het moment van onderzoek heeft $94 \%$ van de afgestudeerden een betaalde baan van minimaal 12 uur per week. Dit is iets hoger dan de $91 \%$ in de vorige enquête en beduidend hoger dan de $85 \%$ in de daaraan voorafgaande meting. Het percentage geregistreerd werklozen bedraagt op dat moment $4 \%$. Dit is iets lager dan de $5 \%$ in de vorige enquête en aanzienlijk lager dan de $10 \%$ in de daaraan voorafgaande enquête. Uit bovenstaande indicatoren blijkt dat de kans op werk de laatste twee jaar sterk is toegenomen. 


\section{Werk vinden}

Evenals bij de vorige enquêtes het geval was, zijn reageren op een advertentie en open solliciteren (elk met een aandeel van $26 \%$ ) de twee belangrijkste kanalen waarmee pas-afgestudeerde economen een werkkring vinden. Overigens stellen afgestudeerde economen zich bij het zoeken naar werk steeds aktiever op: het aandeel van ongevraagd solliciteren (open solliciteren) is namelijk gestaag toegenomen, van $18 \%$ twee jaar geleden naar $23 \%$ vorig jaar en $26 \%$ dit jaar.

\section{Typering werk}

Voor hun werkgelegenheid zijn pas afgestudeerde economen in toenemende mate aangewezen op grote organisaties met minimaal 100 werknemers. Het aandeel van grote organisaties is namelijk toegenomen van $71 \%$ in meting '94 naar $75 \%$ in meting '95 en $78 \%$ in meting ' 96 . De meeste economen ( $88 \%)$ gaan werken in de profit-sector. Bijna tweederde (64\%) oefent een hoger beroep uit, $29 \%$ een wetenschappelijk beroep, $7 \%$ een middelbaar beroep en $1 \%$ een lager beroep.

\section{Functie-eisen}

lets meer dan de helft (52\%) van de betaald-werkende economen heeft een functie op academisch niveau. Dit is nagenoeg gelijk aan de vorige enquête (53\%) en aanzienlijk lager dan de daaraan voorafgaande enquête (61\%). Het lijkt er op dat het vereiste opleidingsniveau stabiliseert.

Driekwart $(77 \%)$ heeft functies die passen bij hun opleidingsrichting (vorig jaar eveneens $77 \%$ en het jaar daarvoor $80 \%$ ). Ruim een kwart (29\%) heeft een functie waarvoor werkervaring is vereist (bij de vorige meting was dit $27 \%$ en het jaar daarvoor $30 \%)$. Een op de vijf $(20 \%)$ afgestudeerde oefent een leidinggevende functie uit (vorige meting $21 \%$ en de meting daarvoor $23 \%$ ).

\section{Arbeidsvoorwaarden}

Evenals twee jaar geleden (95\%) en vorig jaar (96\%) heeft vrijwel iedereen (94\%) een full-time baan (> 32 uur per week). De mate van arbeidsparticipatie blijft dus vrijwel gelijk. De zekerheid van het werk is het afgelopen jaar toegenomen: het aandeel van vaste aanstellingen bedraagt thans $62 \%$ tegen $56 \%$ vorig jaar en $58 \%$ twee jaar geleden. Het gemiddeld bruto maandinkomen is licht gestegen van fl. 3.890 ,- vorig jaar naar fl. 4.020 ,- dit jaar. 


\section{Succesbepalende factoren bij de arbeidsmarktintrede}

In de uitgevoerde analyses van de kans op werk en kwaliteit van het werk blijkt dat vrouwelijke afgestudeerden sneller werk vinden dan mannen en dat oudere afgestudeerden langer werkzoekend zijn dan jongeren.

Economen die voorafgaand aan hun economie-opleiding al een wetenschappelijke of hogere beroepsopleiding hebben voltooid, vinden sneller werk dan anderen. Daar staat echter tegenover dat zij vaker een tijdelijke aanstelling hebben.

De afgestudeerden die vóór of tijdens de economie-opleiding bestuurlijke ervaring of voor het vakgebied relevante werkervaring hebben opgedaan, vinden niet alleen sneller werk maar ook vaker werk dat past bij het genoten opleidingsniveau. Afgestudeerden met relevante werkervaring hebben bovendien meer kans op werk dat past bij de gevolgde opleidingsrichting.

De kans op werk, de zekerheid van het werk en de kans dat het werk aansluit bij de gevolgde opleiding wordt ook bepaald door de gevolgde opleidingsrichting. Vergeleken met algemeen economen (de referentiegroep in de analyses) hebben bedrijfskundigen en econometristen meer kans om snel werk te krijgen. Econometristen hebben bovendien meer kans dat het werk vast is. Afgestudeerden BIK en BE hebben enerzijds minder kans dan algemeen economen om werk op academisch niveau te krijgen, maar anderzijds meer kans dat het werk past bij de gevolgde opleidingsrichting. Fiscaal economen hebben meer kans dan algemeen economen om vast werk te krijgen en werk te vinden dat past bij het niveau en de richting van de gevolgde opleiding.

Een moeizame arbeidsmarktintrede (lang zoeken naar werk) gaat gepaard met een kleinere kans op een vaste baan en eveneens een kleinere kans op een functie die past bij het genoten opleidingsniveau. De kans op een vaste baan neemt toe naarmate men langer is afgestudeerd en het inkomen neemt toe naarmate men langer in de baan werkt.

Vergeleken met de referentie-econoom die in Noordoost-Nederland werkt, hebben betaald-werkende economen in Zuid-Nederland minder kans en in het buitenland werkende economen meer kans op een vaste aanstelling. Economen die in het buitenland werken, hebben bovendien meer kans dat het werk past bij het niveau van een academische opleiding.

In profit organisaties is het loon hoger en de kans op een vaste aanstelling groter dan in de non-profit sector. Daar staat tegenover dat men in profit-organisaties vaker functies moet uitoefenen die niet passen bij het niveau en de richting van de genoten opleiding. 


\section{Voorbereiding op beroepspraktijk}

Veel afgestudeerden beschikken over extra kwalificaties die men vóór of tijdens de economie-opleiding heeft opgedaan, en wel in de vorm van een voltooide HBOopleiding voordat men economie is gaan studeren (19\%, vorig meetjaar eveneens $19 \%$ en de meting daarvoor $18 \%)$, voor het vakgebied relevante werkervaring $(51 \%$, vorig meetjaar $54 \%$ en de meting daarvoor $44 \%$ ), bestuurlijke ervaring $(57 \%$, vorig meetjaar $58 \%$ en de meting daarvoor $60 \%)$ en stage-ervaring $(66 \%$, vorig meetjaar eveneens $66 \%$ ).

Eén op iedere vijf afgestudeerden (20\%) volgt na het afstuderen gedurende kortere of langere tijd verder regulier onderwijs (bijscholing niet meegerekend). Dit is vrijwel gelijk aan de $21 \%$ in de vorige meting en iets meer dan de $18 \%$ de meting daarvoor. Ruim de helft (55\%) neemt deel aan bijscholing (cursorisch onderwijs en bedrijfsopleidingen). Dit is beduidend hoger dan de $45 \%$ in de vorige enquête.

Evenals vorig jaar (83\%) en het jaar daarvoor (82\%) kwalificeert de overgrote meerderheid $(80 \%)$ van de betaald-werkende afgestudeerden de aansluiting tussen de gevolgde opleiding en het uitgeoefende werk als goed of voldoende. Dit laat onverlet dat de oudstudenten slechts matig tevreden zijn over hun voorbereiding op de beroepspraktijk (de voorbereiding op de beroepspraktijk beoordelen zij met een gemiddeld 'rapportcijfer' van 5,8). Meer dan de helft van de oudstudenten acht meer aandacht nodig voor mondelinge en schriftelijke vaardigheden, onderhandelingstechnische en commerciële vaardigheden en informatie- en communicatietechnologie. Met betrekking tot de kennis en vaardigheden die direct verband houden met het vakgebied economie zou de faculteit zich volgens de afgestudeerden vooral meer moeten richten op de praktische toepassingsmogelijkheden van de vakkennis en op de actualiteit daarvan. Aan de vakkennis zelf wordt naar de mening van de afgestudeerden voldoende aandacht besteed.

Hoewel economen een juiste werkhouding door de bank genomen belangrijker achten voor een goede beroepsuitoefening dan kennis en vaardigheden, vinden zij niet dat het economie-onderwijs meer aandacht moet gaan besteden aan houdingsaspecten.

\section{Opleiding achteraf bezien}

De keuzemogelijkheden in het studieprogramma, de samenhang in het vakkenpakket en de kwaliteit van het docentenkorps worden door de afgestudeerden beter beoordeeld dan de studiebegeleiding en de voorlichting over de arbeidsmarkt.

Een op de vijf afgestudeerden vindt dat de opleiding meer gespecialiseerd zou moeten zijn, terwijl $7 \%$ de opleiding te specialistisch vindt. Een opmerkelijk resultaat 
is verder dat maar liefst $28 \%$ van mening is dat de opleiding zwaarder zou mogen worden, terwijl slechts $2 \%$ vindt dat de opleiding minder zwaar zou moeten zijn.

Veruit de meeste economen (86\%) zijn achteraf blij zijn met de destijds gemaakte studiekeuze: zij zouden opnieuw voor dezelfde opleiding kiezen. Eén op zeven betreurt de destijds genomen studiekeuze: zij zouden, achteraf bezien, een andere academische opleiding hebben gekozen, een niet-universitaire opleiding zijn gaan volgen of niet zijn gaan studeren. Als alternatief voor de destijds gekozen opleiding, wordt het vaakst een niet-economische academische opleiding genoemd $(46 \%)$, gevolgd door een andere economische academische opleiding (39\%) en een HBOopleiding (15\%).

De tevredenheid van afgestudeerde economen over hun studiekeuze neemt overigens toe: het aantal spijtoptanten is gedaald van $19 \%$ in meting ' 94 via $18 \%$ in meting '95 naar $14 \%$ in meting ' 96 .

Mobiliteit bij de intrede op de arbeidsmarkt

Een op de vijf afgestudeerden (20\%) werkt buiten de regio waar men heeft gestudeerd. Vorig jaar was dit nog $23 \%$. De geografische mobiliteit is dus iets afgenomen. Zo'n anderhalf jaar na het afstuderen is $39 \%$ (vorige enquête $44 \%$ ) van de betaaldwerkende oudstudenten niet langer in de eerste baan na afstuderen werkzaam. Niet alleen de geografische mobiliteit maar ook de baanmobiliteit is ten opzichte van vorig jaar dus afgenomen.

Bijna de helft (47\%) start de loopbaan in een tijdelijke baan. Gedurende de eerste 18 maanden na het afstuderen veranderen de starters in een tijdelijke baan vaker van baan dan de starters in een vaste baan ( $62 \%$ versus $14 \%)$.

Wat de ontwikkeling van de zekerheid van het werk tijdens de intredeperiode betreft, kunnen afgestudeerden in twee hoofdgroepen worden ingedeeld. In de eerste plaats afgestudeerden die, al dan niet na baanverandering, blijven werken in vaste banen $(55 \%)$ en afgestudeerden waarbij de baanzekerheid is toegenomen (10\%). Aan de andere kant afgestudeerden die, al dan niet na baanverandering, blijven aangewezen op tijdelijke banen (33\%) en afgestudeerden waarbij de baanzekerheid zelfs is afgenomen (3\%).

Wat de ontwikkeling van het niveau van het werk tijdens de intredeperiode betreft, kunnen afgestudeerden in de volgende twee hoofdgroepen worden ingedeeld. In de eerste plaats afgestudeerden die, al dan niet na baanverandering, blijven werken in banen die passen bij het niveau van hun opleiding (45\%) en afgestudeerden waarbij de de match tussen baanniveau en opleidingsniveau is verbeterd (9\%). Aan de andere kant afgestudeerden die, al dan niet na baanverandering, onder hun 
opleidingsniveau blijven werken (42\%) en afgestudeerden waarbij de match tussen baanniveau en opleidingsniveau zelfs is verslechterd $(5 \%)$. Overigens kan uit de resultaten van de analyse van het loon worden afgeleid dat afgestudeerden alleen genegen zijn van baan te veranderen indien hier extra loon tegenover staat. 


\section{Inleiding}

\subsection{Opzet WO-monitor economie}

In opdracht van de economische faculteiten van de Erasmus Universiteit Rotterdam (EUR), de Katholieke Universiteit Brabant (KUB), de Universiteit van Amsterdam (UvA), de Vrije Universiteit (VU) en het College van Bestuur van de Universiteit Maastricht (UM) is eind 1995 - begin 1996 voor de derde keer de WO-monitor economie uitgevoerd. Dit betekent dat de WO-monitor economie thans vrijwel alle pas afgestudeerde economen omvat. Het onderzoeksproject is gericht op het in kaart brengen van de arbeidsmarktintrede van afgestudeerde economen en bestaat uit een schriftelijke enquête. Deze wordt jaarlijks gehouden in de maanden oktoberjanuari onder alle afgestudeerden van het daaraan voorafaande jaar, hetgeen neerkomt op zo'n anderhalf jaar na het afstuderen (afhankelijk van de maand waarin men is afgestudeerd en de maand waarin men de vragenlijst heeft ingevuld). De enquête geeft aldus informatie over de startfuncties van de afgestudeerden. De gehanteerde vragenlijst bevat vragen over de persoon, de afgesloten opleiding, de vooropleiding, de eventuele werk- en bestuurservaring vóór het afstuderen, de belangrijkste activiteiten na het afstuderen tot het moment van enquêteren, de huidige arbeidsmarktpositie, eventueel gevolgd onderwijs na het afstuderen en, bij betaald-werkenden, enkele kenmerken van de huidige functie en van de organisatie waarin men werkzaam is alsmede vragen over de aansluiting van de genoten opleiding op de beroepspraktijk. De definitie en classificatie van de variabelen sluit waar mogelijk aan bij de gangbare indelingen die worden gehanteerd door het Centraal Bureau voor de Statistiek (CBS).

In het derde uitvoeringsjaar, eind 1996/begin 1997, zijn alle economen schriftelijk benaderd, die een getuigschrift hebben behaald bij één van de eerste fase-opleidingen van:

- de Faculteit der Economische Wetenschappen van de EUR, de Faculteit der Economische Wetenschappen en Econometrie van de UvA en de Faculteit der Economische Wetenschappen en Econometrie van de VU, tussen begin september 1994 en eind augustus 1995;

- de Faculteit der Economische Wetenschappen van de KUB, tussen begin januari 1995 en eind december 1995;

- de Faculteit der Economische Wetenschappen en Bedrijfskunde van de UM, tussen begin januari 1995 en eind september 1995.

Het betreft in totaal 2799 afgestudeerde economen. Na de eerste verzending van de vragenlijst is een rappel verstuurd aan de afgestudeerden die toen nog niet hadden gereageerd en is, waar nodig, een tweede schriftelijk rappel uitgevoerd. Tevens heeft in een aantal gevallen een telefonisch rappel plaatsgevonden. Uiteindelijk hebben 1556 afgestudeerden de vragenlijst voor verwerking geschikt ingevuld en 
tijdig geretourneerd, hetgeen neerkomt op een respons van $56 \%$. De inname en verwerking van de enquêteformulieren is eind januari 1997 definitief gestaakt.

De deelnemende faculteiten ontvangen in de eerste plaats een vertrouwelijke faculteitsrapportage waarin per opleiding de resultaten van de eigen faculteit en de desbetreffende totale gegevens van de deelnemende faculteiten samen staan vermeld. Op deze wijze kan de faculteit de positie van haar eigen opleiding ten opzichte van het totale resultaat voor die opleiding bepalen. Het thans voorliggende disciplinerapport economie bevat de resultaten van de vijf deelnemende economische faculteiten samen.

De inhoudelijke opzet van de WO-monitor economie kan als volgt worden beschreven. Afgestudeerden betreden de arbeidsmarkt met bepaalde kenmerken: persoonskenmerken (geslacht, leeftijd en etniciteit), de gevolgde opleidingsrichting en extra kwalificaties die zij vóór of tijdens de studie economie eventueel hebben opgedaan (vooropleiding, werkervaring, bestuurlijke ervaring en eventueel gelopen stage). De persoonskenmerken en gevolgde opleidingsrichting worden in paragraaf 1.2 beschreven; de eventuele extra kwalificaties in paragraaf 5.1. Zowel de persoonskenmerken en de gevolgde opleidingsrichting als de eventueel beschikbare extra kwalificaties worden in dit onderzoek als achtergrondvariabelen gebruikt ter verklaring van eventuele verschillen op de arbeidsmarkt.

De intrede op de arbeidsmarkt vormt het thema van hoofdstuk 2. Om zicht te krijgen op de kans op werk tijdens de intrede zijn drie indicatoren gebruikt, namelijk in paragraaf 2.1 het aantal maanden dat men na het afstuderen in totaal werkzoekend is geweest, en in paragraaf 2.2 de maatschappelijke positie en de werkloosheid op het moment van enquêteren (zo'n anderhalf jaar na afstuderen).

Hoofdstuk 3 gaat in op de huidige banen van de betaald-werkende economen. Het hoofdstuk start in paragraaf 3.1 met een beschrijving van de wijze waarop de economen aan hun baan zijn gekomen. In aansluiting hierop wordt in paragraaf 3.2 nagegaan in welke beroepen zij werkzaam zijn en in wat voor werkorganisaties zij terechtkomen. De werkorganisaties worden getypeerd naar personeelsomvang en bedrijfssector. Vervolgens wordt de kwaliteit van het werk aan de hand van een aantal indicatoren in kaart gebracht. Daartoe wordt in paragraaf 3.3 eerst gekeken naar het opleidingsniveau, de opleidingsrichting en de eventuele werkervaring die voor de functie is vereist. Tevens wordt nagegaan of het een leidinggevende functie betreft. De bespreking van de kwaliteit van het werk wordt in paragraaf 3.4 vervolgd aan de hand van een aantal arbeidsvoorwaarden waarvan er twee nauw verwant zijn aan de kans op werk, namelijk de mate van werkzekerheid en arbeidsparticipatie. In paragraaf 3.4 wordt in dit verband gekeken naar het aandeel van betaaldwerkende afgestudeerden met een vaste aanstelling en naar het aandeel van full- 
time aanstellingen. Als laatste van de arbeidsvoorwaarden wordt gekeken naar de hoogte van het loon.

In hoofdstuk 4 wordt gepoogd om verschillen tussen afgestudeerden met betrekking tot de kans op werk en kwaliteit van het werk nader te verklaren aan de hand van enkele persoons- en kwalificatiekenmerken, de werkregio alsmede enkele kenmerken van de loopbaan, het marktsegment en de uitgeoefende functie.

De voorbereiding op de beroepspraktijk komt aan bod in hoofdstuk 5. De mate waarin afgestudeerde economen op de beroepspraktijk zijn voorbereid, resulteert uit de confrontatie van kwalificaties waarover zij beschikken met kennis en vaardigheden die voor een goede beroepsuitoefening worden vereist. Paragraaf 5.1 gaat in op de extra kwalificaties die zij vóór het afstuderen eventueel hebben opgedaan (vooropleiding, werkervaring, bestuurlijke ervaring en eventueel gelopen stage). De extra kwalificaties die zij na het afstuderen eventueel hebben opgedaan (deelname aan verder regulier onderwijs en bijscholing), komen aan bod in paragraaf 5.2. Vervolgens wordt in paragraaf 5.3 nagegaan welke kennis en vaardigheden van belang zijn voor een goede beroepsuitoefening, waarbij de economen tevens aangeven of deze kennis en vaardigheden wel voldoende aan bod zijn gekomen tijdens hun opleiding. Ook geven zij hun algemeen oordeel over de aansluiting tussen hun economie-opleiding en het werk dat zij hebben.

In hoofdstuk 6 kijken de afgestudeerden terug op hun opleiding. Eerst geven zij aan in welke richting een aantal aspecten van het economie-onderwijs naar hun mening zou moeten worden bijgesteld. Tot slot wordt ingegaan op de vraag of zij, achteraf bezien, wederom dezelfde economie-opleiding zouden kiezen.

In hoofdstuk 7 wordt de mobiliteit tijdens het intredeproces als specifiek thema behandeld.

\subsection{Samenstelling onderzoekspopulatie}

Aan de eind 1996/begin 1997 gehouden enquête hebben in totaal 1556 economen meegewerkt, namelijk 453 afgestudeerden van de EUR (29\%), 423 afgestudeerden van de KUB (27\%), 201 afgestudeerden van de UM (13\%), 274 afgestudeerden van de UvA (18\%) en 205 afgestudeerden van de VU (13\%). Deze respondenten zijn als volgt over de economische opleidingen verdeeld: bedrijfskunde $(6 \%)$, bestuurlijke informatiekunde $(4 \%)$, econometrie $(10 \%)^{1}$ en economie $(80 \%)$. Vanwege het grote aantal afgestudeerden zal de opleiding economie verder worden onderverdeeld in de volgende opleidingsrichtingen: algemene economie, bedrijfseconomie, fiscale

1. Inclusief vijf afgestudeerden kwantitatieve economie en tien afgestudeerden actuariële wetenschappen. 
economie en internationaal management. Vanwege de kleine aantallen afgestudeerden worden de opleidingen bestuurlijke informatiekunde, econometrie en fiscale economie niet verder uitgesplitst naar opleidingsrichting. Tabel 1.1 geeft de verdeling van de 1556 respondenten over de in dit rapport onderscheiden opleidingen.

Tabel 1.1

Gevolgde opleidingen

$\begin{array}{lr}\text { Bedrijfskunde (BK) } & 6 \% \\ \text { Bestuurlijke informatiekunde (BIK) } & 4 \% \\ \text { Econometrie (Ectrie) } & 10 \% \\ \text { Algemene economie (AE) } & 8 \% \\ \text { Bedrijfseconomie (BE) } & 59 \% \\ \text { Fiscale economie (FE) } & 2 \% \\ \text { Internationaal Management (IM) } & 2 \% \\ \text { Economie: overig (Ec-overig) } & 8 \% \\ \text { Totaal } n(=100 \%) & 1556\end{array}$

De categorie Ec-overig (8\%) omvat 130 afgestudeerden, die de volgende opleidingen hebben gevolgd:

- beleidsgerichte economie 2

- internationale economie 3

- sociale en institutionele economie 6

- Japankunde 9

- vrij doctoraal economie 36

- richting binnen economie niet nader aangeduid 74

Hieronder worden de respondenten beschreven aan de hand van drie persoonskenmerken, namelijk geslacht, etniciteit en leeftijd.

Geslacht

Tabel 1.2 laat zien dat economische opleidingen nog steeds 'mannenstudies' zijn: driekwart $(74 \%)$ van de afgestudeerden bestaat uit mannen. Dit laat onverlet dat het aandeel van vrouwelijke economen de afgelopen jaren licht is toegenomen, en wel van $23 \%$ in meting ' 95 via $24 \%$ in meting ' 95 tot $26 \%$ in de afgelopen meting. Wat het aandeel van vrouwelijke afgestudeerden betreft, scoort IM duidelijk hoger dan de andere economische opleidingen.

\section{Etniciteit}

In de enquête is gevraagd tot welke bevolkingsgroep de afgestudeerde zichzelf rekent. Tabel 1.2 toont dat 'slechts' $2 \%$ van de bevraagde economen zichzelf tot een allochtone bevolkingsgroep rekent. 
Leeftijd

De gemiddelde leeftijd op het moment van enquêteren, dat wil zeggen zo'n anderhalf jaar na afstuderen, bedraagt 26,5 jaar (tabel 1.2). Bij de vorige enquête was dit 26,4 en het jaar daarvoor 26,2. Econometristen zijn gemiddeld het jongst en fiscaal economen het oudst. 


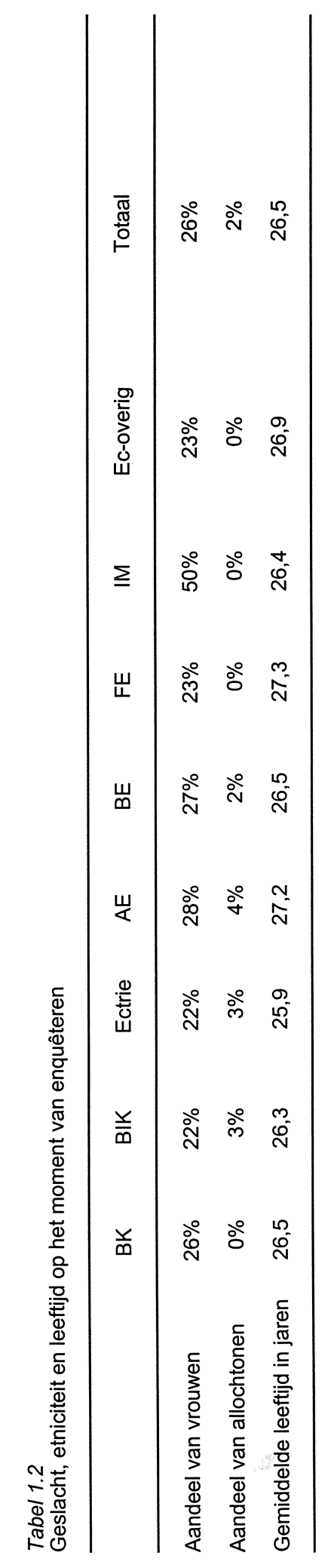




\section{Intrede op de arbeidsmarkt}

\subsection{Zoeken naar werk}

In deze paragraaf wordt ingegaan op het zoeken naar werk door de afgestudeerden. Eerst komt aan bod of de oudstudenten tijdens of ná de WO-opleiding actief naar betaald werk hebben gezocht en zo ja, wanneer zij begonnen zijn werk te zoeken. Vervolgens wordt nagegaan hoe lang zij naar werk hebben gezocht.

Aan de afgestudeerden is de vraag voorgelegd of zij tijdens of ná de WO-opleiding actief hebben gezocht naar betaald werk, bijbaantjes of vakantiewerk niet meegerekend. Tabel 2.1 laat zien dat een op iedere zes afgestudeerden (17\%) niet naar werk heeft gezocht, bijvoorbeeld omdat men al een baan had tijdens de studie. Aan de overgrote meerderheid van de afgestudeerden die wel naar werk hebben gezocht (83\%), is vervolgens gevraagd wanneer zij zijn begonnen met het actief zoeken naar betaald werk. Tabel 2.2 laat zien dat een derde van de afgestudeerden (36\%) ruimschoots (meer dan een drie maanden) vóór het afstuderen begint met actief naar werk te zoeken. De helft (52\%) begint rond het afstuderen (tussen drie maanden vóór en een maand na afstuderen) te zoeken, terwijl een op de acht afgestudeerden (12\%) wacht tot meer dan één maand na afstuderen alvorens actief naar werk te gaan zoeken. Tabel 2.2 laat verder zien dat met name fiscaal economen al ruimschoots voor afstuderen naar werk beginnen te zoeken.

Het totaal aantal maanden dat men na het afstuderen werkloos is geweest, geeft een indicatie van de mate waarin de intrede op de arbeidsmarkt meer of minder succesvol is verlopen. Welnu, in een kalender hebben de afgestudeerden voor iedere maand na het afstuderen aangegeven welke maatschappelijke situatie (waaronder 'werkloos') zijzelf het beste vonden passen bij hun omstandigheden. De afgestudeerde mocht per maand slechts één bezigheid omcirkelen. In tegenstelling tot de afgelopen jaren hoefden de afgestudeerden niet per definitie 'betaald werk' als belangrijkste bezigheid aan te geven indien men minimaal 12 uur per week werkte, en één van de andere categorieën als men minder dan 12 uur per week werk had. Het gaat hier derhalve om een subjectieve maat voor werkloosheid. In tabel 2.3 is de totale tijdsduur aangegeven die de afgestudeerden tussen de maand van afstuderen en de enquêtemaand werkloos zijn geweest. Dit cijfer is alleen berekend voor degenen die zich tijdens deze 'intredeperiode' op enigerlei moment hebben aangeboden op de arbeidsmarkt. Dat wil zeggen zij hebben in die periode ooit betaald werk verricht en/of zijn ooit werkloos geweest. Het gaat hier om de totale werkloosheidsduur in de genoemde periode, aaneengesloten dan wel onderbroken door eventuele andere bezigheden. 


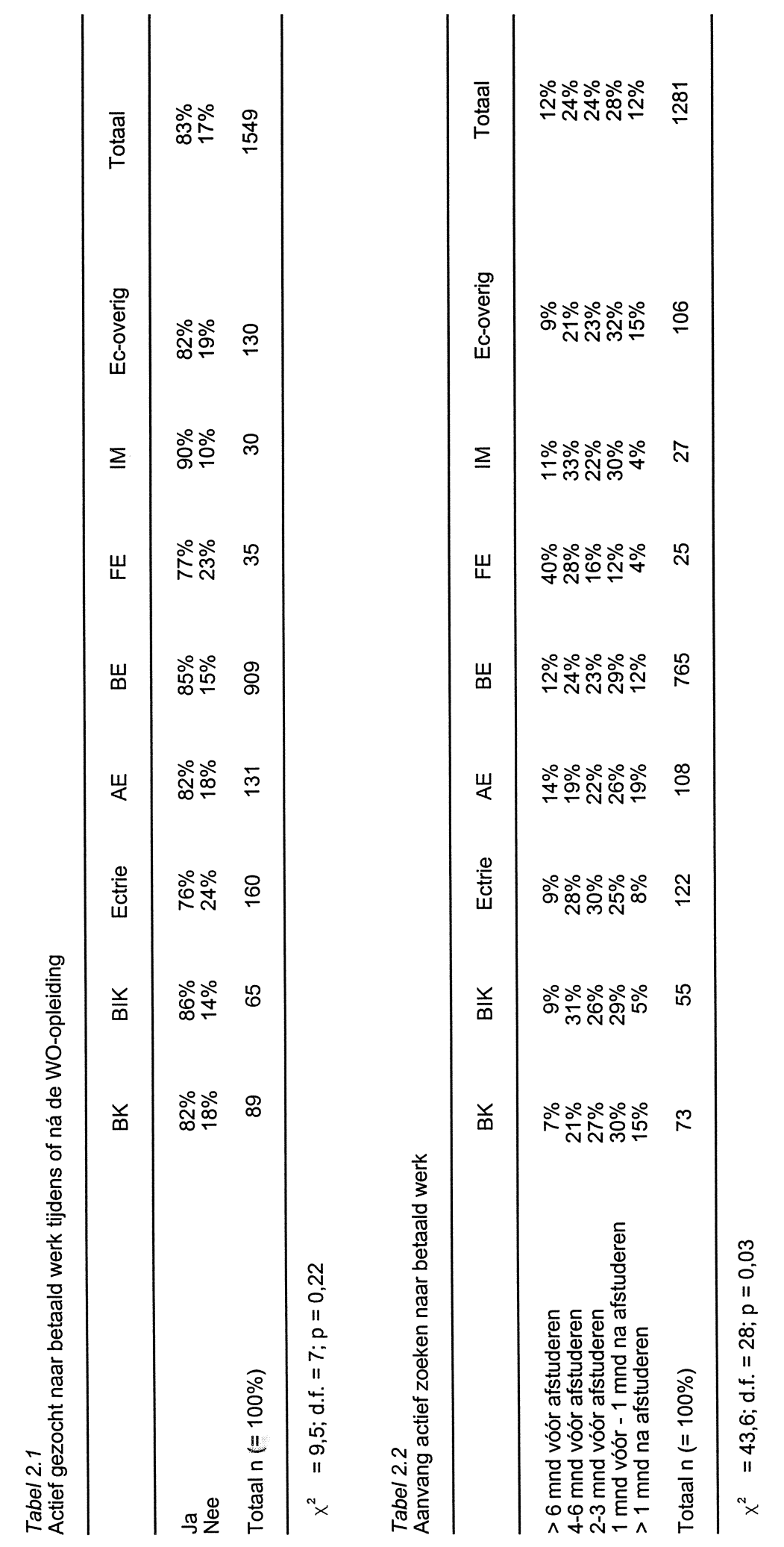


Tabel 2.3 laat zien dat tweederde (65\%) van alle afgestudeerden niet werkloos is geweest tijdens de intredeperiode, dat wil zeggen tussen de maand van afstuderen en de enquêtemaand. Dit is een verbetering ten opzichte van de vorige enquête (53\% niet werkzoekend geweest) en de daaraan voorafgaande meting (48\% niet werkzoekend geweest). Afgestudeerde economen vinden dus steeds sneller werk.

\subsection{Maatschappelijke positie op enquêtemoment}

\section{Maatschappelijke positie}

Tabel 2.4 geeft een beeld van de maatschappelijke situatie op het moment van de enquête. Het betreft de positie, aangegeven door de afgestudeerden, welke zijzelf het beste vonden passen bij hun omstandigheden. Het gaat hier derhalve om een subjectieve maat.

Gegeven het feit dat de meeste afgestudeerden rond de zomer van 1995 zijn afgestudeerd en de enquête eind 1996 is gehouden, gaat het in deze tabel doorgaans om de situatie zo'n anderhalf jaar na afstuderen (afhankelijk van de maand waarin men is afgestudeerd en de maand waarin men de vragenlijst heeft ingevuld).

Zo'n anderhalf jaar na het afstuderen is vrijwel iedereen (94\%) betaald werkzaam. (dit is iets hoger dan de $91 \%$ in de vorige enquête en beduidend hoger dan de $85 \%$ in de daaraan voorafgaande meting); $4 \%$ beschouwt zichzelf als werkloos en $2 \%$ geeft aan dat zij student zijn (tabel 2.4). De resterende $1 \%$ vervult militaire/vervangende dienst, verricht onbetaald werk of is anderszins bezig.

\section{Werkloosheid}

Bij het bespreken van de intredewerkloosheid en de maatschappelijke positie is steeds het begrip 'werkloos' gebruikt. Het gaat hierbij om afgestudeerden die van zichzelf vinden dat zij in een bepaalde maand werkloos zijn geweest. Het procentuele aandeel van deze afgestudeerden in de totale populatie is in de kerncijfers van de faculteitsrapportages die de deelnemende faculteiten ontvangen onder het kopje 'werkloos op enquêtemoment' gepresenteerd. De hier in tabel 2.5 gepresenteerde werkloosheidspercentages hebben echter betrekking op de definitie van 'geregistreerde werkloosheid', zoals die door het CBS wordt gehanteerd. Conform deze CBS-definitie worden afgestudeerden met een leeftijd van $16 \mathrm{t} / \mathrm{m} 64$ jaar gerekend tot de geregistreerde werklozen wanneer zij:

- zijn ingeschreven bij het arbeidsbureau, èn

- tenminste 12 uur per week betaald werk willen verrichten, èn

- op het enquêtemoment geen betaald werk voor tenminste 12 uur per week hebben, èn 


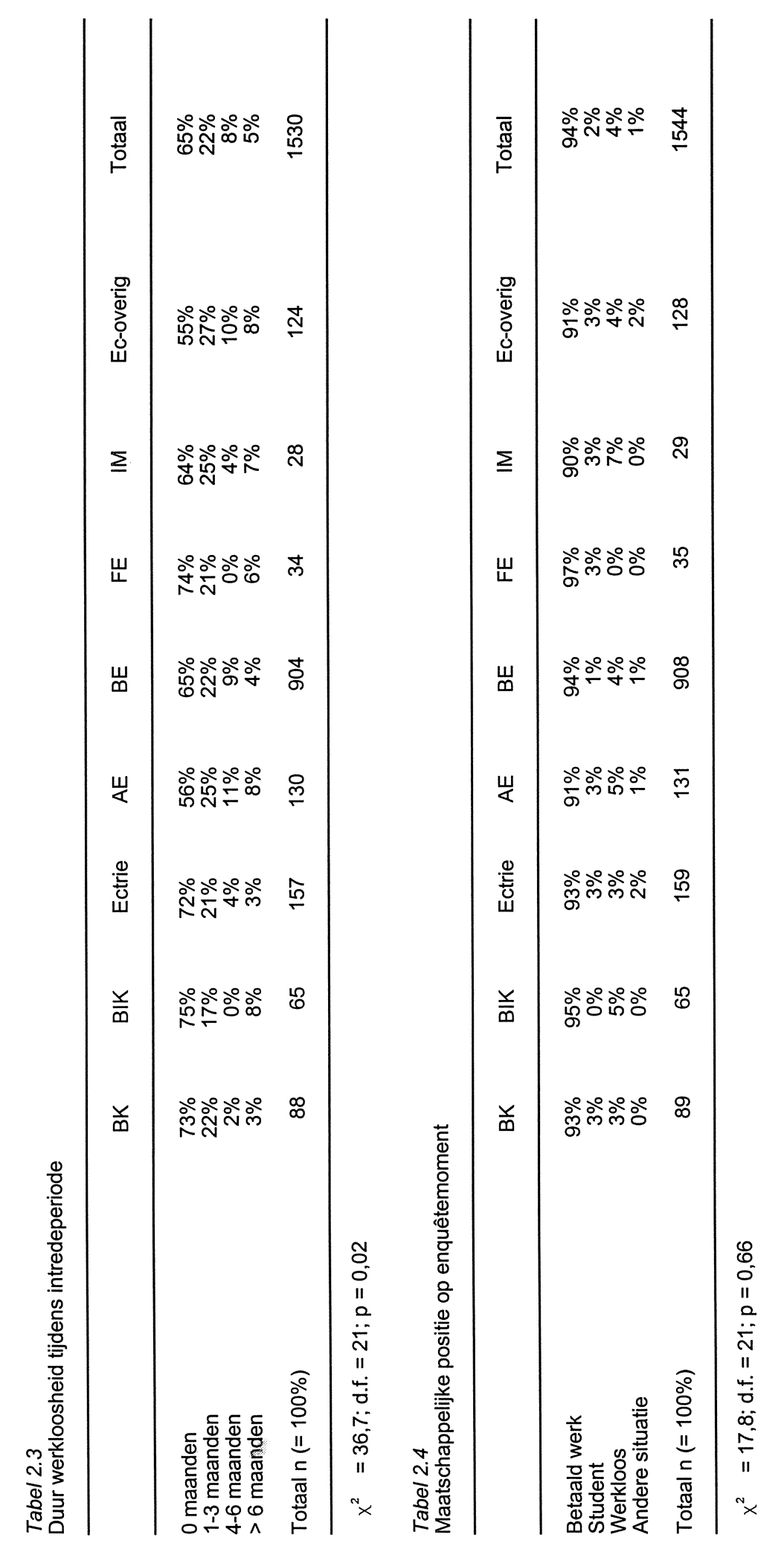


- beschikbaar zijn voor een baan van tenminste 12 uur per week (d.w.z. binnen twee weken kunnen beginnen of anders binnen drie maanden in verband met opzegtermijn huidige werkkring, het afronden van vrijwilligerswerk, het regelen van kinderopvang, vakantie of ziekte), òf:

- betaald werk hebben aanvaard waarvoor men tenminste 12 uur per week gaat werken.

Voor het berekenen van het werkloosheidspercentage wordt het aantal geregistreerde werkloze afgestudeerden uitgedrukt als percentage van de afgestudeerden die tot de beroepsbevolking behoren. Welnu, conform CBS-definitie worden afgestudeerden tot de beroepsbevolking gerekend wanneer zij:

- tenminste 12 uur per week betaald werken, òf

- militaire of vervangende dienstplicht vervullen, òf

- betaald werk hebben aanvaard waarvoor zij tenminste 12 uur per week gaan werken, òf

- verklaren tenminste 12 uur per week betaald werk te willen verrichten, daarvoor beschikbaar zijn èn activiteiten ontplooien om betaald werk voor tenminste 12 uur per week te vinden.

Aldus gedefinieerd, bedraagt de werkloosheid, gemeten zo'n anderhalf jaar na afstuderen, gemiddeld $4 \%$ (tabel 2.5). Dit is iets lager dan de $5 \%$ van de vorige enquête en beduidend lager dan de $10 \%$ van de daaraan voorafgaande enquête.

\section{Werkzame personen op enquêtemoment}

Zo'n anderhalf jaar na het afstuderen kan 93\% van de economen tot de groep 'werkzame personen' worden gerekend (tabel 2.5). Deze groep wordt gevormd door de afgestudeerden die minimaal 12 uur per week betaald werk hebben en niet 'student' als maatschappelijke positie hebben opgegeven. Bij afgestudeerden die op het moment van de enquête meer dan één baan hebben, gaat het om het totaal aantal arbeidsuren van deze banen. In de voorafgaande jaren kan het aantal 'werkenden' zijn overschat, omdat toendertijd ook de studenten die minimaal 12 uur per week werkten tot de 'werkenden' zijn gerekend.

Het aandeel van werkzame personen is van belang voor de interpretatie van de cijfers over de werkende afgestudeerden. De tabellen over hun baankenmerken in hoofdstuk 3 betreffen de baan met de meeste arbeidsuren. 


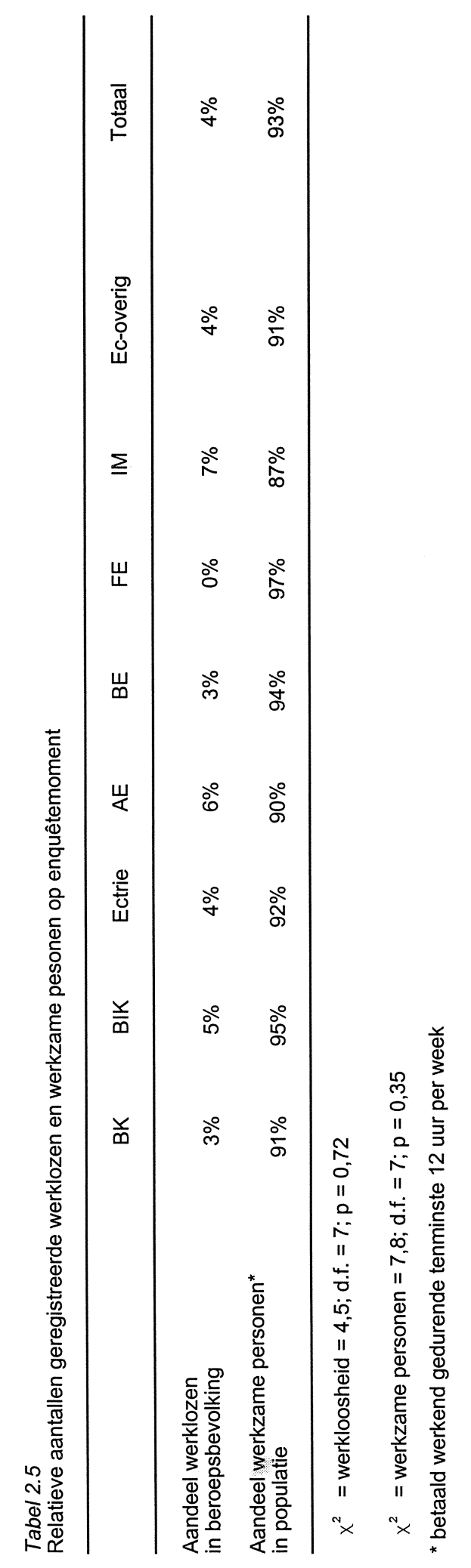




\section{Baankenmerken}

\subsection{Functieverwerving}

In dit hoofdstuk komen de betaalde functies van economen aan bod. Het gaat hierbij om afgestudeerden die op het moment van enquêteren, dus circa anderhalf jaar na afstuderen, in totaal (hoofd- en eventuele nevenfuncties samen) tenminste 12 uur per week betaald werken en niet 'student' als maatschappelijke positie hebben aangegeven. In het geval dat iemand meerdere betaalde functies heeft, hebben de gepresenteerde resultaten betrekking op de functie met het grootste aantal arbeidsuren. Voordat de kenmerken van de baan aan bod komen, wordt eerst nagegaan op welke wijze men de baan heeft verkregen. Vervolgens wordt de werkkring getypeerd waarbinnen de functie wordt uitgeoefend en wordt aangegeven in welke beroepsklassen economen werkzaam zijn. Daarna komen de eisen aan bod die door de werkgever voor de vervulling van de functie worden gesteld, gevolgd door enkele arbeidsvoorwaarden.

Tabel 3.1 laat zien dat reageren op een advertentie en ongevraagd solliciteren (elk met een aandeel van $26 \%$ ) de twee belangrijkste kanalen zijn waarmee pas afgestudeerde economen werk vinden. Eén op iedere zeven afgestudeerden krijgt werk via een uitzendbureau of commercieel bemiddelingsbureau (14\%), een op de elf afgestudeerden via stages ( $9 \%$ ), een op de twaalf via familie, vrienden of kennissen $(8 \%)$ en een op iedere twintig afgestudeerden via eerder werk of een interne vacature $(5 \%)$. Minder belangrijk zijn in dit verband de universiteit (docent/ vacaturebank/alumnibureau/loopbaanadviescentrum e.d.) met $4 \%$ en bedrijveninformatiedagen/banenmarkten/open dagen van bedrijven met $2 \%$. Verder komt naar voren dat 'slechts' $1 \%$ zelf een eigen bedrijf start of het bedrijf van bijvoorbeeld de ouders overneemt, en slechts $1 \%$ werk vindt via het Arbeidsbureau.

Ook in de vorige enquêtes kwam naar voren dat advertenties en open sollicitaties de belangrijkste kanalen zijn om een baan te krijgen. Afgestudeerde economen stellen zich bij het zoeken naar werk overigens steeds aktiever op. Dit kan worden afgeleid uit het gestaag toegenomen aandeel van ongevraagd solliciteren (van 18\% twee jaar geleden en $23 \%$ vorig jaar naar $26 \%$ dit jaar).

Met betrekking tot sommige kanalen waarmee economen werk vinden, manifesteren zich duidelijke verschillen tussen de opleidingen. Zo blijken uitzendbureaus/ commerciële bemiddelingsbureaus en stages voor bedrijfskundigen belangrijker te zijn dan voor andere economen, behoudens econometristen voor wie stages even belangrijk zijn. Naast stages zijn docenten relatief belangrijk voor econometristen om aan een baan te komen. Docenten zijn ook relatief belangrijk voor afgestudeerden IM. Fiscaal economen vinden vaker dan anderen werk via advertenties. Afgestu- 


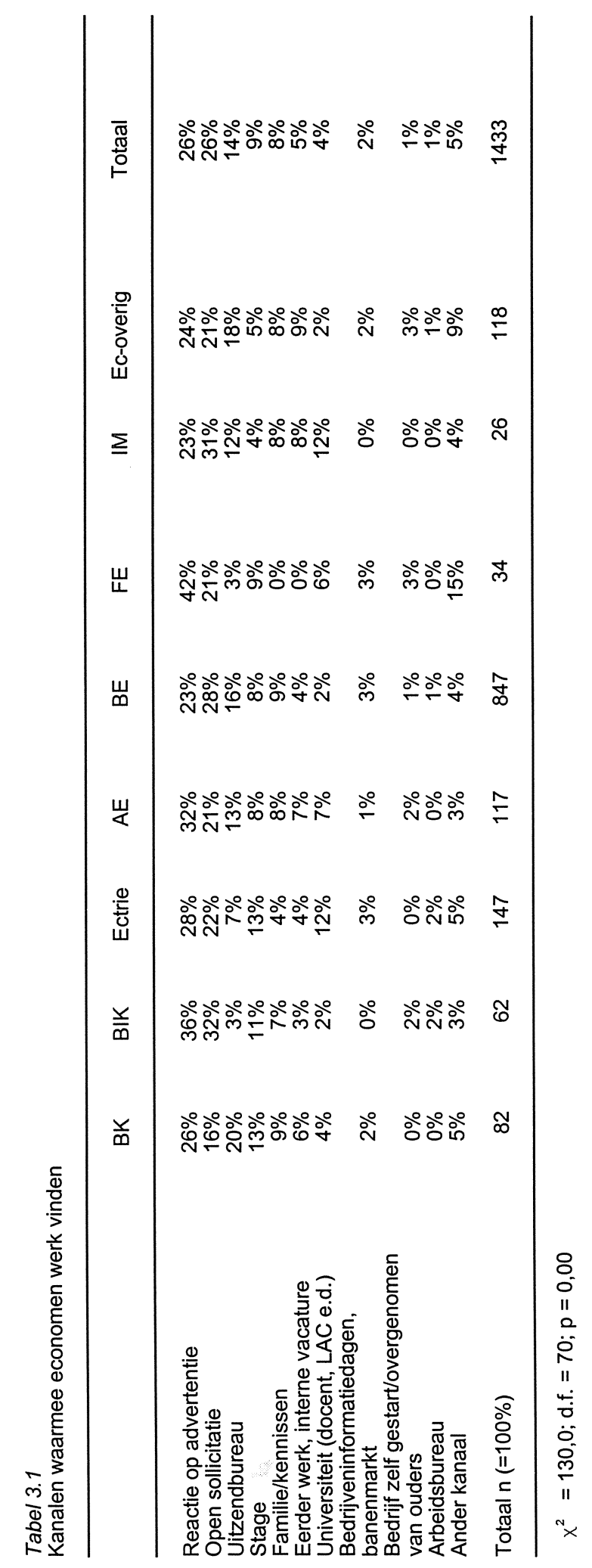


deerden BIK krijgen vaker dan andere economen werk door ongevraagd te solliciteren.

\subsection{Typering werk}

In deze paragraaf worden eerst de organisaties waarin de afgestudeerden op het moment van enquêteren werken, getypeerd naar personeelsomvang en bedrijfssector. Vervolgens komt het beroep aan bod.

\section{Bedrijfsomvang}

Tabel 3.2 typeert de werkgelegenheid van economen naar de grootte van het bedrijf of de organisatie waar men werkt. Het gaat daarbij om het aantal werknemers bij het gehele concern. Naar voren komt dat ruim driekwart $(78 \%)$ van de economen in grote organisaties werkt, dat wil zeggen in bedrijven of instellingen met minimaal 100 werknemers. Eén op de zes $(17 \%)$ is werkzaam in een middelgrote organisatie (10 tot 100 werknemers), terwij $5 \%$ terecht komt in organisaties met maximaal 9 werknemers. Van alle afgestudeerden werken econometristen het vaakst in grote organisaties, algemeen economen in middelgrote organisaties en afgestudeerden IM in kleine organisaties.

Het lijkt er overigens op dat pas afgestudeerde economen steeds vaker in grote bedrijven terecht komen. Het aandeel van grote bedrijven is namelijk toegenomen van $70 \%$ in meting ' 94 naar $75 \%$ in meting ' 95 tot $78 \%$ in meting ' 96 .

\section{Marktsector}

De meeste $(88 \%)$ economen komen terecht in op profit gerichte organisaties; 'slechts' $12 \%$ werkt in de non-profit sector. Van alle afgestudeerde economen werkt $42 \%$ in de handel in (on)roerend goed/zakelijke dienstverlening, $21 \%$ bij financiële instellingen, $12 \%$ in de industrie, $6 \%$ in reparatie/handel consumentenartikelen, $6 \%$ bij het openbaar bestuur, $5 \%$ in de sector vervoer/opslag/communicatie, $4 \%$ in het onderwijs en $4 \%$ verspreid over overige sectoren.

Tabel 3.3 geeft per opleiding een meer gedetailleerd beeld van de bedrijfsklassen waarin afgestudeerde economen terecht komen. In deze tabel zijn alleen bedrijfsklassen opgenomen waarin tenminste $5 \%$ van de betaald-werkende afgestudeerden van de desbetreffende opleiding werkzaam is.

\section{Beroep}

Van alle afgestudeerde economen oefent $64 \%$ een hoger beroep uit, $29 \%$ een wetenschappelijk beroep, $7 \%$ een middelbaar beroep en $1 \%$ een lager beroep. De 


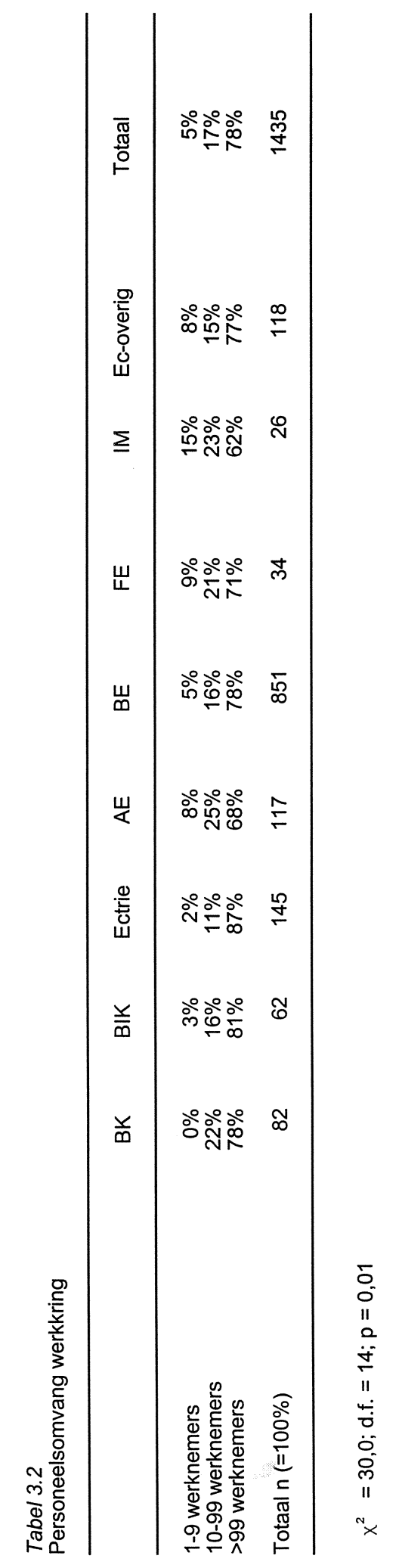


Tabel 3.3

Belangrijkste bedrijfsklassen

Afgestudeerden BK:

$\begin{array}{ll}\text { - geldscheppende financiële instellingen } & 16 \%\end{array}$

- adviesbureaus automatisering, systeemhuizen $15 \%$

- verzekeringswezen/pensioenfondsen $9 \%$

- accountant/boekhoudbureaus $6 \%$

- economisch onderzoeks-/adviesbureaus $\quad 5 \%$

- uitzend-/arbeidsbemiddelingsbureaus $\quad 5 \%$

Afgestudeerden BIK:

- adviesbureaus automatisering, systeemhuizen $\quad 52 \%$

- economisch onderzoeks-/adviesbureaus $13 \%$

$\begin{array}{ll}\text { - geldscheppende financiële instellingen } & 7 \%\end{array}$

Afgestudeerden Econometrie:

- adviesbureaus automatisering, systeemhuizen $\quad 20 \%$

- geldscheppende financiële instellingen $13 \%$

$12 \%$

- verzekeringswezen/pensioenfondsen $6 \%$

- systeemontwikkelings-/analysedienst, programmeerdienst $5 \%$

- accountant/boekhoudbureaus $\quad 5 \%$

Afgestudeerden AE:

- algemeen overheidsbestuur $\quad 18 \%$

- geldscheppende financiële instellingen $\quad 10 \%$

- economisch onderzoeks-/adviesbureaus $\quad 7 \%$

- technische ontwikkelingsbureaus $6 \%$

Afgestudeerden BE:

- accountant/boekhoudbureaus $\quad 17 \%$

- geldscheppende financiële instellingen $11 \%$

- adviesbureaus automatisering, systeemhuizen $\quad 10 \%$

- economische onderzoeks-/adviesbureaus $5 \%$

Afgestudeerden FE:

- accountant/boekhoudbureaus $\quad 79 \%$

- algemeen overheidsbestuur $\quad 6 \%$

Afgestudeerden IM:
- zakelijke dienstverlening

$\begin{array}{lr}\text { - zakelijke dienstverlening } & 16 \% \\ \text { - automobielindustrie } & 8 \%\end{array}$

- telecommunicatie $\quad 8 \%$

- geldscheppende financiële instellingen $\quad 8 \%$

- adviesbureaus automatisering, systeemhuizen $\quad 8 \%$

Afgestudeerden Ec-overig:

- geldscheppende financiële instellingen $\quad 16 \%$

- adviesbureaus automatisering, systeemhuizen $\quad 9 \%$

- accountant/boekhoudbureaus

drie belangrijkste beroepsklassen zijn: hogere administratieve, commerciële, economische beroepen (60\%), wetenschappelijke economische, administratieve beroepen $(23 \%)$ en middelbare administratieve, commerciële beroepen $(5 \%)$.

Tabel 3.4 geeft per opleiding een overzicht van de belangrijkste beroepen van de betaald-werkende afgestudeerden. Hierbij worden alleen de beroepen vermeld 
waarin tenminste $5 \%$ van de betaald-werkende afgestudeerden van de desbetreffende opleiding werken.

Tabel 3.4

Belangrijkste beroepen

Afgestudeerden BK

- financieel adviseur; kredietanalist

$12 \%$

- automatiseringsadviseur

- econoom (excl. wetenschappelijk onderzoek)

$10 \%$

- wetenschappelijke bedrifsorganisatiedeskundige

- hogere bedrijfsorganisatiedeskundige $\quad 5 \%$

Afgestudeerden BIK:

- automatiseringsadviseur

- projectadviseur automatisering

- systeemprogrammeur (wetenschappelijke toepassingen)

- systeemanalist/-ontwerper

- manager/medewerker kwaliteitszorg

- assistent-accountant, administrateur

- wetenschappelijke bedrijfsorganisatiedeskundige

Afgestudeerden Econometrie:

- wetenschappelijk onderzoeker econometrie

- systeemprogrammeur (wetenschappelijke toepassingen)

- actuaris

- financieel adviseur; kredietanalist

- automatiseringsadviseur

Afgestudeerden AE:

- wetenschappelijk onderzoeker algemene economie $\quad 7 \%$

- financieel adviseur; kredietanalist $6 \%$

- beleidsmedewerker algemeen economische zaken $\quad 5 \%$

- beleidsambtenaar algemeen economische zaken $\quad 5 \%$

Afgestudeerden BE:

- assistent-accountant

- (bedrijfs)econoom (excl. wetenschappelijk onderzoek) $9 \%$

- financieel adviseur; kredietanalist $\quad 9 \%$

- automatiseringsadviseur $\quad 5 \%$

- boekhouder $\quad 5 \%$

Afgestudeerden FE:

- belastingconsulent (wetenschappelijk) $\quad 59 \%$

- belastingconsulent (hoger) $\quad 21 \%$

$\begin{array}{ll}\text { - inspecteur belastingen } & 6 \%\end{array}$

Afgestudeerden IM:

- wetenschappelijk onderzoeker marketing $\quad 12 \%$

- marketing-onderzoeker $12 \%$

- marketingadviseur/-specialist $12 \%$

- hogere bedrijfsorganisatiedeskundige $\quad 8 \%$

- wetenschappelijke bedrijfsorganisatiedeskundige $\quad 8 \%$

- hoofd kleine afdeling verkoop $\quad 8 \%$

- vertegenwoordiger technische produkten $\quad 8 \%$

Afgestudeerden Ec-overig:

- financieel adviseur; kredietanalist

- (bedrijfs)econoom (excl. wetenschappelijk onderzoek) $8 \%$

- assistent-accountant $6 \%$ 


\subsection{Functievereisten}

In deze paragraaf wordt ingegaan op de eisen die door de werkgevers zijn gesteld bij de werving en selectie voor de functies die de afgestudeerden op het enquêtemoment vervullen. Daarbij komt eerst de vereiste opleidingsrichting en het vereiste opleidingsniveau aan bod. Vervolgens wordt ingegaan op de vraag of werkervaring werd vereist voor de functie. Tot slot wordt nagegaan of het een leidinggevende functie betreft.

\section{Vereiste opleidingsrichting}

De opleidingsrichting die door de werkgever voor de vervulling van de functie werd vereist, geeft aan of de afgestudeerde al dan niet binnen het 'eigen' beroependomein terecht komt. Van het 'eigen' beroependomein is sprake wanneer voor de desbetreffende functie (uitsluitend) de eigen opleidingsrichting of een daaraan verwante opleidingsrichting werd vereist. Buiten het eigen beroependomein is sprake van concurrentie door afgestudeerden van andere opleidingsrichtingen. Dit is het geval wanneer voor de desbetreffende functie geen specifieke opleidingsrichting of een geheel andere dan de eigen opleidingsrichting werd vereist.

Tabel 3.5 geeft aan hoeveel procent van de betaald-werkende afgestudeerden binnen het eigen beroependomein werkt. Naar voren komt dat de meeste economen $(77 \%)$ functies uitoefenen die passen bij hun opleidingsrichting (bij de vorige meting was dit eveneens $77 \%$ en bij de daaraan voorafgaande meting $80 \%$ ). Van alle afgestudeerden zijn oudstudenten FE het vaakst binnen het eigen domein werkzaam.

\section{Vereist opleidingsniveau}

Naast de vereiste opleidingsrichting is in de enquête gevraagd naar het opleidingsniveau dat door de werkgever voor de vervulling van de functie werd vereist. Wat het minimaal vereiste opleidingsniveau betreft, kan een hoofdonderscheid worden gemaakt tussen functies waarvoor een opleiding op academisch niveau niet is vereist en functies waarvoor men een academische opleiding moet hebben gevolgd. Wanneer een academische opleiding niet is vereist voor de vervulde functie is er sprake van potentiële onderbenutting van capaciteiten bij de uitoefening van de functie. Hierbij mag evenwel niet worden vergeten dat het gaat om startfuncties, waarbij doorgroei mogelijk is naar een niveau dat wel aansluit bij de gevolgde opleiding. 


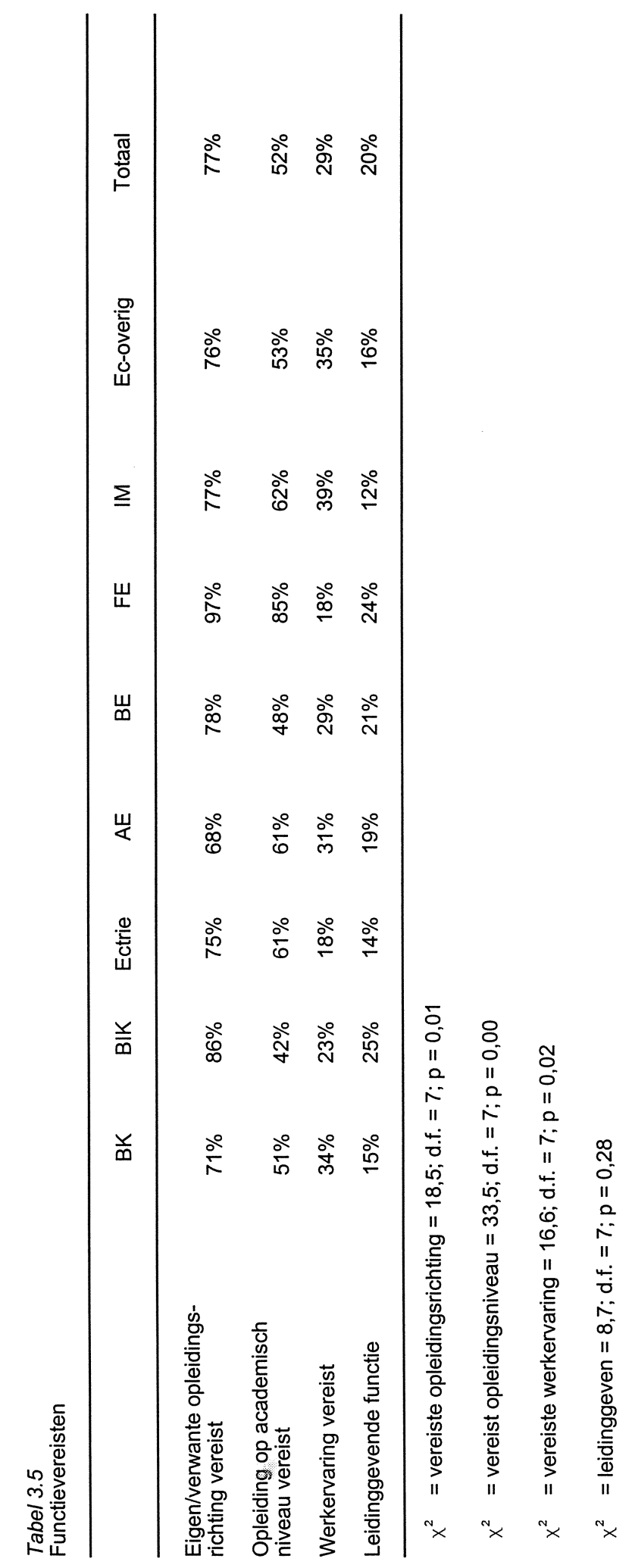


Tabel 3.5 laat zien dat slechts iets meer dan de helft (52\%, vorige meting $53 \%$ ) van de betaald-werkende afgestudeerden een functie op academisch niveau heeft (fiscaal economen komen het vaakst terecht in functies op academisch niveau). Dit betekent dat bijna de helft werkzaam is in functies die ook door opgeleiden op een lager niveau, bijvoorbeeld HBO'ers, kunnen worden vervuld. Hierbij kan een rol spelen dat de academische economische opleidingen pendantopleidingen op een lager niveau hebben, namelijk in het HEAO. Ter vergelijking: niemand van de afgestudeerden geneeskunde van de UM, een academische opleiding zonder pendantopleidingen op een lager niveau, is werkzaam in een functie die ook door niet-academisch opgeleiden kan worden vervuld.

Bij de meting in 1994 had nog $61 \%$ van pas afgestudeerde economen een functie op academisch niveau. Bij de meting in 1995 was dit teruggelopen tot $53 \%$ en thans bedraagt het percentage 52 . Het lijkt er op dat de toename van het werken onder het opleidingsniveau is afgezwakt en het gemiddelde vereiste opleidingsniveau zich stabiliseert.

\section{Vereiste werkervaring}

Het laatste aspect met betrekking tot de eisen die door de werkgever bij de werving en selectie zijn gesteld, betreft het al dan niet vereist zijn van werkervaring. Tabel 3.5 laat zien dat $29 \%$ van de afgestudeerden aangeeft dat voor de functie werkervaring werd vereist (bij de vorige meting was dit $27 \%$ en het jaar daarvoor $30 \%$ ). Het geringe aandeel van banen waarvoor werkervaring werd vereist, is niet verwonderlijk aangezien het gaat om intreders op de arbeidsmarkt. Tabel 3.5 laat verder zien dat het percentage werkenden met een baan waarvoor werkervaring werd vereist het hoogst is onder afgestudeerden IM en het laagst onder econometristen en fiscaal economen.

\section{Leidinggeven}

Gebleken is dat 'slechts' een op de vijf $(20 \%)$ betaald-werkende afgestudeerden een leidinggevende functie heeft (tabel 3.5). Dit is niet verwonderlijk omdat deze populatie nog aan het begin van de beroepscarrière staat. Het aandeel van pas afgestudeerde economen in leidinggevende functies bedroeg in de vorige meting $21 \%$ en de meting daarvoor $23 \%$.

\subsection{Arbeidsvoorwaarden}

In deze paragraaf over de arbeidsvoorwaarden van pas afgestudeerde economen komen eerst het soort dienstverband, de duur van de aanstelling en de wekelijkse arbeidsduur aan bod. Vervolgens wordt ingegaan op de hoogte van het loon. 


\section{Dienstverband en aanstellingsduur}

Van de betaald-werkende respondenten werkt $92 \%$ (vorige meting $89 \%$ ) in loondienst bij een werkgever en $4 \%$ (vorige meting $7 \%$ ) via een uitzendbureau. Slechts $2 \%$ (vorige meting eveneens $2 \%$ ) werkt als zelfstandige in een eigen bedrijf danwel freelance. De overige $2 \%$ werkt als oproepkracht (0-uren contract of $\mathrm{min} / \mathrm{max}$ contract), via een werkervaringsproject of als meewerkend gezinslid met of zonder arbeidscontract in het bedrijf van de ouders/partner. Per saldo is $97 \%$ (vorige meting $98 \%$ ) van alle betaald-werkende afgestudeerden op contractuele basis werkzaam (dus exclusief de zelfstandigen en freelancers).

Aan de betaald-werkende economen die op contractuele basis werken, is gevraagd wat de aard van hun aanstelling is. Tabel 3.6 laat zien dat, gemeten circa anderhalf jaar na het afstuderen, ruim de helft $(62 \%)$ al een vaste aanstelling heeft. Dit is hoger dan bij de vorige meting ( $56 \%$ vaste aanstellingen) en de daaraan voorafgaande meting (58\% vaste aanstellingen). Niet alleen de kans op werk (zie hoofdstuk 2) maar ook de zekerheid van het werk is dus toegenomen. Overigens hebben fiscaal economen het vaakst een vaste baan.

\section{Wekelijkse arbeidsduur}

Dit aspect van de arbeidsvoorwaarden geeft een indicatie van de mate van arbeidsparticipatie. Tabel 3.6 geeft aan hoeveel betaald-werkende afgestudeerden een fulltime baan hebben, dat wil zeggen een baan van minimaal 33 uur per week. Wanneer men meerdere banen heeft, wordt uitgegaan van de baan met het grootste aantal arbeidsuren. Tabel 3.6 laat zien dat vrijwel iedereen (94\%) in voltijd werkt en dat zich hierbij geen grote verschillen tussen de opleidingsrichtingen voordoen. Bij de vorige meting bedroeg het aandeel van full-time banen $96 \%$ en het jaar daarvoor $95 \%$. De mate van arbeidsparticipatie is dus nagenoeg gelijk gebleven.

$\mathrm{Er}$ is ook nagegaan of zich ten aanzien van dit baanaspect verschillen tussen mannen en vrouwen manifesteren. Deze blijken niet significant te zijn. Van de betaald-werkende mannen heeft $95 \%$ een full-time baan; bij de vrouwen bedraagt het percentage $93 \%$.

Loon

Als laatste baankenmerk komt het loon aan bod, dat betaald-werkende economen zo'n anderhalf jaar na het afstuderen verdienen. Aansluitend bij de definitie die het CBS hanteert bij het jaarlijks onderzoek naar de verdiende lonen, is in de enquête achtereenvolgens voor de hoofdfunctie en eventuele nevenfunctie(s) gevraagd naar het bruto maandloon: 
- inclusief eventuele toeslagen voor onregelmatig werk, ploegendienst, provisie en dergelijke;

- exclusief inkomsten uit overwerk en bijzondere uitkeringen zoals 13e maand, winstdeling, gratificatie, vakantiegeld, kinderbijslag, vergoeding voor reiskosten en kleding, en dergelijke.

Tabel 3.6 laat zien dat betaald-werkende economen zo'n anderhalf jaar na het afstuderen gemiddeld 4.020 gulden bruto per maand verdienen. Dit is inclusief eventuele nevenfunctie(s). Fiscaal economen verdienen gemiddeld het meest. Bij de vorige enquête bedroeg het gemiddeld bruto maandloon 3.890 en het jaar daarvoor 3.930 gulden.

In tabel 3.6 is tevens vermeld hoeveel afgestudeerden minder verdienen dan het wettelijk minimum maandloon en daarmee in feite niet (structureel) in het eigen levensonderhoud kunnen voorzien. Het wettelijk vastgestelde minimumloon is afhankelijk van de leeftijd en bedraagt voor iemand van tenminste 23 jaar 2.220 gulden bruto per maand (bron: Arbeidsinspectie 1 januari 1997). De tabel laat zien dat $2 \%$ (bij de vorige meting $3 \%$ ) van de betaald-werkende afgestudeerden een inkomen uit arbeid beneden het minimumloon heeft. Dit varieert van $0 \%$ bij afgestudeerden $\mathrm{BIK}$ en $\mathrm{FE}$ tot $6 \%$ bij econometristen. Hierbij kunnen echter verschillen in de lengte van de werkweek een rol spelen. Om de lonen hiervoor te corrigeren zijn eveneens de bruto uurlonen berekend (incl. toeslagen, doch excl. nevenfuncties). Per uur verdienen betaald-werkende afgestudeerden gemiddeld 23,30 gulden bruto in hun hoofdfunctie. Dit betekent dat het uurloon weer exact even hoog is als twee jaar geleden, na het vorige jaar te zijn gedaald tot 22,40 gulden. Fiscaal economen verdienen per uur gemiddeld het meest en econometristen het minst (tabel 3.6). 


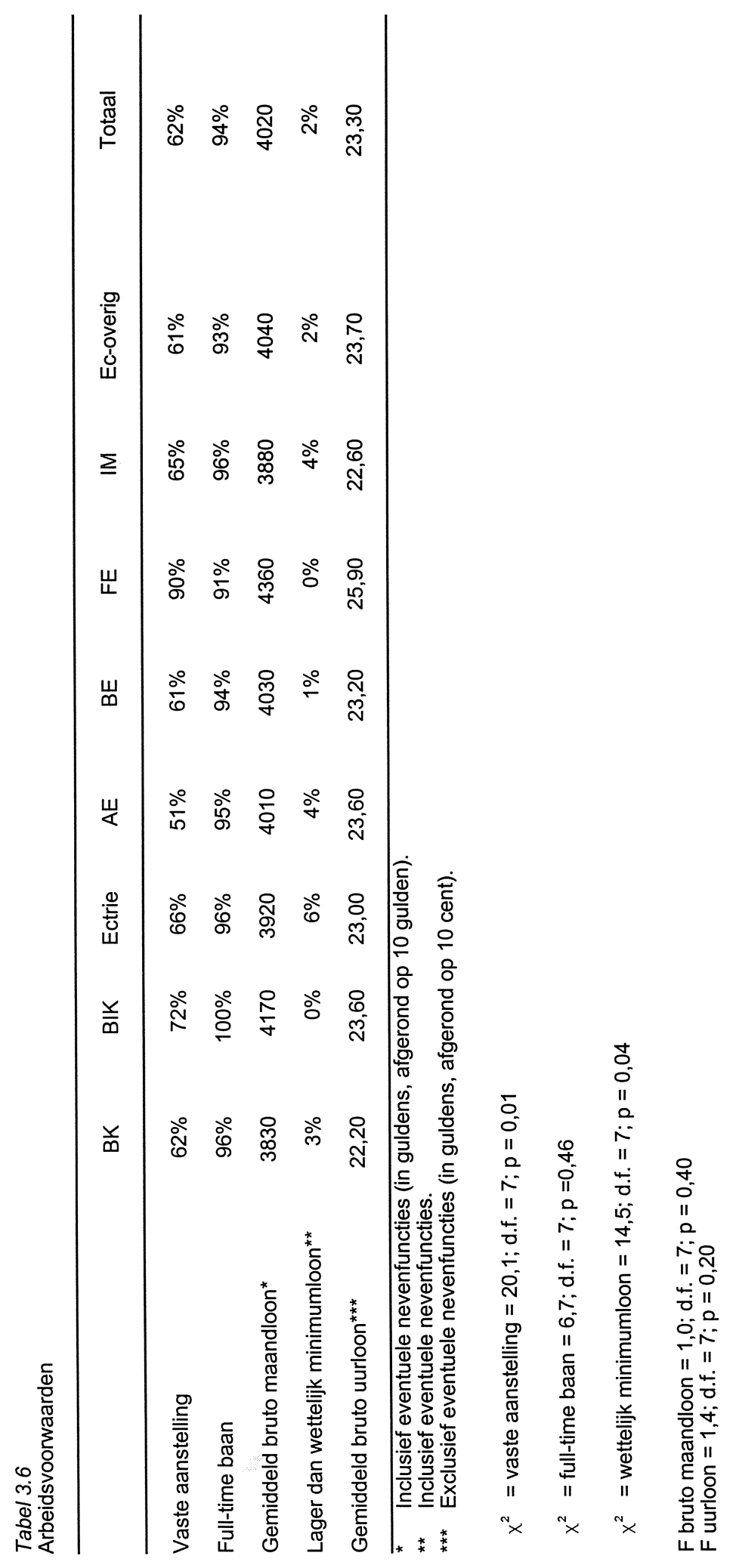




\section{Factoren die de arbeidsmarktpositie beïnvloeden}

In dit rapport worden twee dimensies van de transitie van studie naar werk nader geanalyseerd, namelijk de kans op werk en de kwaliteit van het werk. De kans op werk wordt geanalyseerd aan de hand van de volgende twee indicatoren:

- $\quad$ het snel (binnen drie maanden) vinden van werk;

- $\quad$ het hebben van een vaste aanstelling.

De kwaliteit van het werk wordt geanalyseerd aan de hand van drie indicatoren:

- $\quad$ een baan waarvoor een opleiding op academisch niveau is vereist;

- $\quad$ werk waarvoor de eigen- of een daaraan verwante opleidingsrichting is vereist;

- de hoogte van het bruto uurloon.

\section{Toelichting op de afhankelijke variabelen}

Met behulp van logistische regressie-analyse is eerst nagegaan welke factoren van invloed zijn op het al dan niet snel vinden van werk. In de analyse heeft een afgestudeerde een goede kans op betaald werk wanneer hij of zij in de periode tussen afstuderen en de enquête niet of in totaal hooguit drie maanden op zoek is geweest naar betaald werk. De referentiegroep wordt gevormd door degenen die tijdens de periode tussen afstuderen en enquêteren in totaal langer dan drie maanden naar werk hebben gezocht. De analyse heeft uitsluitend betrekking op afgestudeerden die zich na het afstuderen ooit op de arbeidsmarkt hebben aangeboden: zij hebben in die periode ooit betaald werk verricht en/of zijn ooit werkzoekend geweest.

Vervolgens is voor de afgestudeerden die op contractuele basis werken met behulp van logistische regressie-analyse nagegaan welke kenmerken een verklaring kunnen bieden voor de kans op een vaste aanstelling. De referentiegroep wordt gevormd door degenen die een tijdelijk arbeidscontract hebben.

Daarna is nagegaan welke factoren van invloed zijn op de kans om terecht te komen in banen die passen bij de gevolgde opleiding. Om deze vraag te kunnen beantwoorden, is eerst de kans geschat dat voor de baan de eigen opleidingsrichting of een daaraan verwante opleidingsrichting is vereist. Daarnaast is de kans geschat dat de baan wat het vereiste opleidingsniveau betreft, past bij de genoten opleiding. Zoals gezegd, is eerst de kans geschat dat voor de functie de eigen of een verwante opleidingsrichting is vereist. Als referentiecategorie zijn functies genomen waarvoor geen specifieke, of een geheel andere opleidingsrichting is vereist. Daarnaast is de kans geschat dat voor de functie een opleiding op academisch niveau is vereist. Als referentiegroep voor degenen die op hun niveau werken, fungeerden de oudstudenten die onder hun opleidingsniveau werken. 
Met behulp van lineaire regressie-analyse is tenslotte nagegaan welke kenmerken van invloed zijn op (de logaritme van) het bruto uurloon van de betaald-werkende afgestudeerden. Het bruto uurloon (incl. toeslagen) is berekend voor de hoofdfunctie van de afgestudeerden, dus excl. de inkomsten uit eventuele nevenfuncties.

\section{Toelichting op de verklarende variabelen}

In de analyses is een aantal verklarende variabelen opgenomen waarvan wordt aangenomen dat zij de werkzekerheid en kwaliteit van het werk kunnen beïnvloeden, namelijk enkele persoonskenmerken, de gevolgde opleidingsrichting, additionele kwalificaties waarover afgestudeerden eventueel beschikken, het soort werkorganisatie, de werkregio alsmede enkele kenmerken van de loopbaan.

De in de analyse opgenomen persoonskenmerken betreffen het geslacht (geslacht: man) en de leeftijd op het moment van afstuderen (leeftijd). De eventuele extra kwalificaties, opgedaan vóór of tijdens de opleiding betreffen het reeds beschikken over een diploma van een opleiding in het hoger onderwijs voordat men aan de economische faculteit kwam studeren (HO-vooropleiding), het beschikken over bestuurlijke ervaring, het beschikken over voor het vakgebied relevante (on)betaalde werkervaring (exclusief stages): relevante werkervaring en het beschikken over stage-ervaring. In de analyse zijn de volgende dummy-variabelen voor de gevolgde opleiding opgenomen: bedrijfskunde $(B K)$, bestuurlijke informatiekunde $(B I K)$, Econometrie, algemene economie $(A E)$, bedrijfseconomie $(B E)$, fiscale economie $(F E)$, internationaal management $(I M)$ en de overige economische opleidingsrichtingen (Economie-overig).

Voor het soort werkorganisatie zijn twee dummy-variabelen in de analyse opgenomen, namelijk het werken in een profit-organisatie (profit-sector) en het werken in organisatie met meer dan 100 werknemers (grote organisatie). Met eventuele regionale verschillen in de werkgelegenheidssituatie is in de analyse rekening gehouden door het opnemen van de variabele werkregio (noordoost-Nederland, west-Nederland, zuid-Nederland en het buitenland).

De in de analyse opgenomen kenmerken van de loopbaan betreffen in de eerste plaats de wijze waarop de arbeidsmarktintrede is verlopen. Deze wordt geoperationaliseerd door het niet of ten hoogste drie maanden werkzoekend zijn geweest (direkte intrede). Daarnaast is in enkele analyses het verloop van de match tussen opleidingsniveau en baanniveau gedurende de intredeperiode opgenomen. Hierbij doen zich op het moment van de enquête zes mogelijkheden voor: de respondent werkt nog steeds in de qua niveau passende intredebaan (match is goed zonder mobiliteit); na verandering van baan heeft de respondent opnieuw niveau-passend werk (match blijt goed na mobiliteit); de respondent had een intredebaan onder zijn niveau, veranderde van baan en heeft thans niveau-passend werk (match verbetert 
na mobiliteit); de respondent had een intredebaan op zijn niveau, veranderde van baan en heeft thans een baan onder zijn niveau (match verslechtert na mobiliteit); de respondent werkt nog steeds in de intredebaan die onder zijn niveau is (match is slecht zonder mobiliteit); na verandering van baan heeft de respondent opnieuw werk onder zijn niveau (match blijft slecht na mobiliteit).

De verklarende variabelen zijn geoperationaliseerd met behulp van dummy-variabelen, met uitzondering van de leeftijd in jaren (leeftijd), het aantal maanden dat men in de huidige baan werkzaam is en het aantal maanden dat men reeds is afgestudeerd ( $n$ maanden afgestudeerd). Het laatste kenmerk, het aantal maanden tussen het moment van afstuderen en het moment van enquêteren, is in de analyse opgenomen om te kunnen corrigeren voor ongelijke perioden van arbeidsmarktintrede.

Met betrekking tot de variabele leeftijd dient te worden vermeld dat $4 \%$ van de respondenten ouder dan 30 jaar is. Om te voorkomen dat de relatief hoge leeftijden van deze minderheid een te zware wissel zouden trekken op de analyseresultaten zijn deze dertigplussers niet meegenomen in de analyses. Voor de precieze omschrijving van de verklarende variabelen wordt verwezen naar bijlage 1 . In de schattingen fungeerde $A E$ als referentie voor de gevolgde opleiding, het noordoosten van Nederland (noordoost-Nederland) als referentie voor de werkregio en match blijft slecht na mobiliteit als referentie voor het verloop van de match tussen opleidingsniveau en baanniveau.

Er wordt verondersteld dat de werkzekerheid en de kwaliteit van het werk per economische opleiding kan verschillen. Verder wordt verwacht dat vrouwen zich met minder succes dan mannen op de arbeidsmarkt aanbieden. Vanwege een aantal redenen mag worden verwacht dat jongeren betere kansen op de arbeidsmarkt hebben dan ouderen. Jongeren zijn doorgaans flexibeler dan ouderen en kunnen zich daardoor wellicht makkelijker aanpassen aan de specifieke cultuur van een werkorganisatie. Bovendien zullen jongeren wellicht eerder bereid zijn om aanvullende (bedrijfsspecifieke) opleidingen te volgen, aangezien hun investering in aanvullend onderwijs gedurende een groter aantal arbeidsjaren tot een hoger loon zal leiden. Vanuit de werkgever gezien kunnen de in bedrijfsopleidingen geïnvesteerde tijd en kosten, middels de verwachte hogere arbeidsproductiviteit, bij jongeren over een groter aantal arbeidsjaren worden terugverdiend. Daarbij komt dat voor jongeren, vanwege het groter aantal arbeidsjaren dat zij nog voor zich hebben, een flexibeler loopbaanplanning mogelijk is: zij zijn makkelijker in lagere startfuncties inzetbaar om van daaruit, mede door het volgen van bedrijfsspecifieke opleidingen, door te stromen naar hogere functies in de organisatie. Extra kwalificaties in de vorm van het reeds beschikken over een HO-diploma vóórdat men economie gaat studeren alsmede voor het vakgebied relevante werkervaring en bestuurlijke ervaring, opgedaan vóór of tijdens de economiestudie vergroten iemands menselijk 
kapitaal, maken iemand productiever en daarmee voor een werkgever aantrekkelijker, waardoor de kansen op de arbeidsmarkt toenemen.

Volgens de baanmatchingtheorie resulteert de produktiviteit van individuen zowel uit de specifieke kennis en vaardigheden waarover zij beschikken als uit de specifieke functie waarin deze kennnis en vaardigheden worden toegepast. De verwachting is dan ook dat de produktiviteit en daarmee het loon toeneemt naarmate de match tussen opleidingsniveau en functieniveau beter is.

Op basis van de hiervoor genoemde veronderstellingen en de wijze waarop de variabelen zijn geoperationaliseerd, worden positieve effecten verwacht voor geslacht en voor de extra kwalificaties waarover men eventueel beschikt. Voor leeftijd wordt een negatief teken verwacht.

\section{Invloed van persoonskenmerken op arbeidsmarktsucces}

Het geslacht blijkt wel een significant effect te hebben op de kans op werk, maar niet op de zekerheid van het werk noch op de kwaliteit van het werk dat men krijgt. In de uitgevoerde analyse van de kans op direkte intrede blijkt dat vrouwelijke afgestudeerden sneller werk vinden dan mannen.

Oudere afgestudeerden zijn langer werkzoekend dan jongere afgestudeerden. Mogelijk zijn de oudere afgestudeerden langer werkzoekend omdat zij kieskeuriger zijn in het accepteren van een baan dan jongeren. Oudere afgestudeerden hebben namelijk een hoger loon.

\section{Invloed van kwalificaties op arbeidsmarktsucces}

In de uitgevoerde analyses kon geen significant effect van stage-ervaring op arbeidsmarktsucces worden vastgesteld. Wel blijkt dat economen die voorafgaand aan hun economie-opleiding al een wetenschappelijke of hogere beroepsopleiding hebben voltooid in het voordeel zijn ten opzichte van de andere economen wat betreft de kans om snel werk te krijgen. Daar staat echter tegenover dat zij vaker een tijdelijke aanstelling hebben.

De afgestudeerden die vóór of tijdens de economie-opleiding bestuurlijke ervaring of voor het vakgebied relevante werkervaring hebben opgedaan, vinden niet alleen sneller werk maar ook vaker werk dat past bij het genoten opleidingsniveau. Afgestudeerden met relevante werkervaring hebben bovendien meer kans op werk dat past bij de gevolgde opleidingsrichting.

Additionele kwalificaties die men vóór of tijdens de opleiding heeft opgedaan, komen vooralsnog niet tot uiting in een hoger loon. Wellicht hebben afgestudeerden met 
additionele kwalificaties hun 'meerwaarde' nog niet in de vorm van een hogere produktiviteit aan hun werkgever zichtbaar kunnen maken.

De kans op werk, de zekerheid van het werk en de kans dat het werk aansluit bij de gevolgde opleiding wordt ook bepaald door de gevolgde opleidingsrichting. Vergeleken met algemeen economen (de referentiegroep in de analyses) hebben bedrijfskundigen en econometristen meer kans om snel werk te krijgen. Econometristen hebben bovendien meer kans dat het werk vast is. Afgestudeerden BIK en BE hebben enerzijds minder kans dan algemeen economen om werk op academisch niveau te krijgen, maar anderzijds meer kans dat het werk past bij de gevolgde opleidingsrichting. Fiscaal economen hebben meer kans dan algemeen economen om vast werk te krijgen en werk te vinden dat past bij het niveau en de richting van de gevolgde opleiding.

Invloed loopbaan op arbeidsmarktsucces

Degenen die een weinig succesvolle start hebben op de arbeidsmarkt (dat wil zeggen lang hebben moeten zoeken naar werk) hebben een kleinere kans op een vaste baan en eveneens een kleinere kans op een functie die past bij het genoten opleidingsniveau. De kans op een vaste baan neemt toe naarmate men langer is afgestudeerd en het inkomen neemt toe naarmate men langer in de baan werkt.

Voor de bespreking van het effect op het loon van de wijze waarop de match tussen opleidingsniveau en baanniveau tijdens het intredeproces is verlopen, wordt verwezen naar hoofdstuk 7 .

\section{Invloed werkregio op arbeidsmarktsucces}

Vergeleken met de referentie-econoom die in Noordoost-Nederland werkt, hebben de betaald-werkende economen in Zuid-Nederland minder kans en de in het buitenland werkende economen meer kans op een vaste aanstelling. Economen die in het buitenland werken, hebben bovendien meer kans dat het werk past bij het niveau van een academische opleiding.

Invloed marktsegment op arbeidsmarktsucces

Pas afgestudeerde economen die in de profit organisaties gaan werken, verdienen meer en hebben meer kans op een vaste aanstelling dan hun collega's in de nonprofit sector. Daar staat evenwel tegenover dat men in profit-organisaties vaker functies moet uitoefenen die niet passen bij het niveau en de richting van de genoten opleiding. 
Tabel 4.1

Logistische regressie-analyse van de kans op werk en zekerheid van het werk

\begin{tabular}{|c|c|c|c|c|}
\hline & \multicolumn{2}{|c|}{$\begin{array}{l}<=3 \text { maanden } \\
\text { werkzoekend }\end{array}$} & \multicolumn{2}{|c|}{ Vaste baan } \\
\hline & B & SE & B & SE \\
\hline $\begin{array}{l}\text { Persoonskenmerken: } \\
\text { - geslacht: man } \\
\text { - leeftijd }\end{array}$ & $\begin{array}{l}-.51^{*} \\
-.29^{\star *}\end{array}$ & $\begin{array}{l}.22 \\
.05\end{array}$ & $\begin{array}{l}.15 \\
.07\end{array}$ & $\begin{array}{l}.14 \\
.05\end{array}$ \\
\hline $\begin{array}{l}\text { Extra kwalificaties vóór afstuderen: } \\
\text { - HO-vooropleiding } \\
\text { - bestuurlijke ervaring } \\
\text { - relevante werkervaring } \\
\text { - stage-ervaring }\end{array}$ & $\begin{array}{l}.49^{*} \\
.48^{\star *} \\
.72^{\star *} \\
.18\end{array}$ & $\begin{array}{l}.22 \\
.17 \\
.18 \\
.17\end{array}$ & $\begin{array}{l}-.36^{*} \\
.20 \\
.08 \\
.19\end{array}$ & $\begin{array}{l}.16 \\
.13 \\
.13 \\
.14\end{array}$ \\
\hline $\begin{array}{l}\text { Opleidingsrichting: } \\
\text { - BK } \\
\text { - BIK } \\
\text { - Econometrie } \\
\text { - AE } \\
\text { - BE } \\
\text { - FE } \\
\text { - IM } \\
\text { - Economie-overig }\end{array}$ & $\begin{array}{l}1.11^{*} \\
1.14 \\
1.01^{*} \\
\text { refe } \\
.21 \\
1.08 \\
.12 \\
.08\end{array}$ & $\begin{array}{r}.54 \\
.65 \\
.41 \\
\text { ntie } \\
.28 \\
.79 \\
.69 \\
.36\end{array}$ & $\begin{array}{c}.02 \\
.50 \\
.71^{*} \\
\text { refe } \\
.29 \\
2.03^{\star *} \\
.80 \\
.41\end{array}$ & $\begin{array}{r}.34 \\
.39 \\
.31 \\
\text { atie } \\
.25 \\
.69 \\
.58 \\
.32\end{array}$ \\
\hline $\begin{array}{l}\text { Kenmerken intrede: } \\
\text { - } n \text { maanden afgestudeerd } \\
\text { - direkte intrede }\end{array}$ & -.01 & $\stackrel{.03}{x}$ & $\begin{array}{r}.07^{\star *} \\
1.41^{\star *}\end{array}$ & $\begin{array}{l}.02 \\
.21\end{array}$ \\
\hline $\begin{array}{l}\text { Werkregio: } \\
\text { - noordoost-Nederland } \\
\text { referentie } \\
\text { - west-Nederland } \\
\text { - zuid-Nederland } \\
\text { - buitenland }\end{array}$ & $x$ & $x$ & $\begin{array}{l}-.23 \\
-.61^{\star} \\
.98^{*}\end{array}$ & $\begin{array}{l}.25 \\
.27 \\
.50\end{array}$ \\
\hline $\begin{array}{l}\text { Marktsegmentkenmerken: } \\
\text { - profit-sector } \\
\text { - grote organisatie }\end{array}$ & $x$ & $x$ & $\begin{array}{l}1.95^{\star \star} \\
.23\end{array}$ & $\begin{array}{l}.22 \\
.15\end{array}$ \\
\hline Constante & $8.71^{* *}$ & 1.41 & $-5.92^{\star *}$ & 1.27 \\
\hline 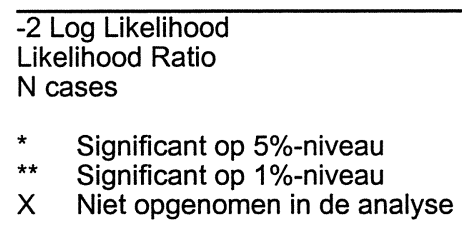 & $\begin{array}{r}98 \\
8 \\
142\end{array}$ & & & $\begin{array}{l}8.7 \\
0.5^{\star \star}\end{array}$ \\
\hline
\end{tabular}


Tabel 4.2

Logistische regressie-analyse van het niveau en de richting van het werk

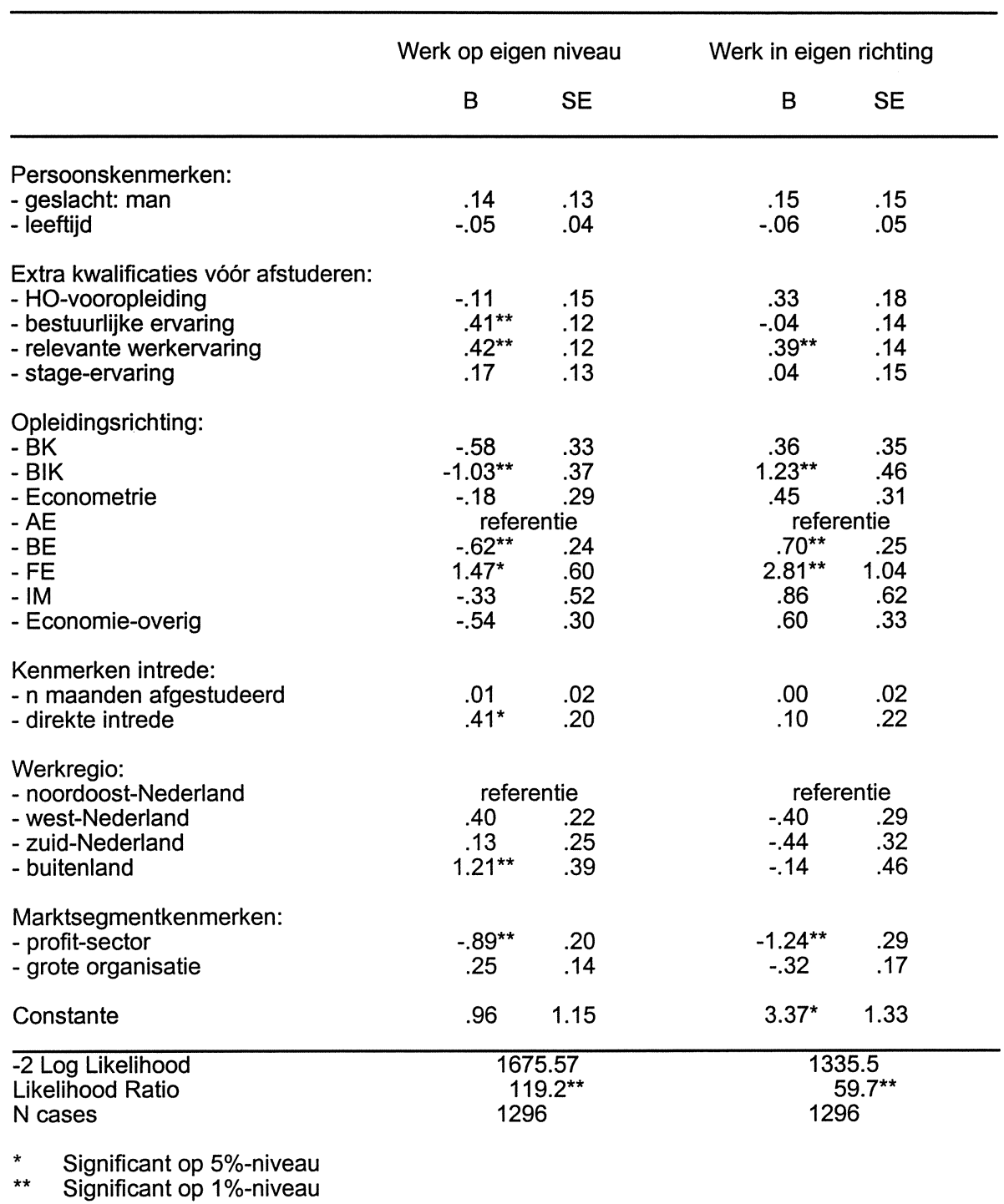


Tabel 4.3

Lineaire regressie-analyse van het bruto uurloon

B $\quad t$

Persoonskenmerken:

- geslacht: man

- leeftijd

$.00 \quad .21$

Extra kwalificaties vóór afstuderen:

- HO-vooropleiding

- bestuurlijke ervaring

- relevante werkervaring

- stage-ervaring

Opleidingsrichting:

- BK

- BIK

- Econometrie

- AE

$\begin{array}{ll}.01 & .89 \\ .01 & 74 \\ .02 & 1.26\end{array}$

$.02 \quad 1.26$

$.03 \quad 1.89$

$-B E$

- FE

- IM

- Economie-overig

$-.04 \quad-1.10$

$\begin{array}{ll}.04 & 1.02 \\ -.01 & -.34\end{array}$

referentie

$-.34$

$.01 \quad .45$

$.01 \quad .14$

$.04 \quad .68$

Kenmerken intrede:

- direkte intrede

- $\mathrm{n}$ maanden in baan

$.00 \quad .08$

$.01^{* *} \quad 7.86$

Match opleidingsniveau-functieniveau:

- goed zonder mobiliteit

- blijft goed na mobiliteit

- verbetert na mobiliteit

- verslechtert na mobiliteit

- slecht zonder mobiliteit

- blijft slecht na mobiliteit

$\begin{array}{lr}.06^{*} & 2.48 \\ .07^{*} & 2.09 \\ .08^{*} & 2.58 \\ .06 & 1.60 \\ .06 & -.22 \\ -.00 & \text { referentie }\end{array}$

Werkregio:

- noordoost Nederland

- west-Nederland

- zuid-Nederland

- buitenland

referentie

$.01 \quad .25$

$\begin{array}{rr}-.03 & -1.22 \\ .07 & 1.61\end{array}$

Marktsegmentkenmerken:

- profit-sector

$\begin{array}{ll}05^{*} & 2.47 \\ & \end{array}$

- grote organisatie

$.03-1.94$

Constante

$2.60^{* *}$

19.40

\begin{tabular}{lr}
\hline R-kwadraat & .13 \\
$\mathrm{~F}$ & $6.09^{\star *}$ \\
$\mathrm{~N}$ cases & 1015
\end{tabular}

1015

* $\quad$ Significant op 5\%-niveau

* $\quad$ Significant op $1 \%$-niveau 


\section{Voorbereiding op beroepspraktijk}

\subsection{Vóór het afstuderen opgedane extra kwalificaties}

De mate waarin afgestudeerde economen op de beroepspraktijk zijn voorbereid, resulteert uit de confrontatie van kwalificaties waarover zij beschikken met kennis en vaardigheden die voor een goede beroepsuitoefening worden vereist. De kwalificaties waarover afgestudeerde economen beschikken, worden in de eerste plaats bepaald door de economische opleidingsrichting die zij hebben gevolgd. Daarnaast kunnen zij vóór, tijdens of na hun opleiding addditionele kwalificaties hebben opgedaan. Het gaat hierbij om zowel formele als informele kwalificaties die het functioneren binnen arbeidsorganisaties en op de arbeidsmarkt beïnvloeden. Formele kwalificaties zijn kwalificaties die men in het reguliere onderwijs verwerft, terwijl informele kwalificaties worden opgedaan buiten het reguliere onderwijs, bijvoorbeeld in een werkkring of in een bestuurlijke functie.

Deze paragraaf gaat in op de extra kwalificaties die vóór het afstuderen eventueel zijn opgedaan. De extra kwalificaties die economen na het afstuderen eventueel hebben opgedaan, komen aan bod in paragraaf 5.2. Tot slot wordt in paragraaf 5.3 nagegaan welke kennis en vaardigheden van belang zijn voor een goede beroepsuitoefening, waarbij de economen tevens aangeven of deze kennis en vaardigheden wel voldoende aan bod zijn gekomen tijdens hun opleiding. Ook geven zij hun algemeen oordeel over de aansluiting tussen hun economie-opleiding en het werk dat zij hebben en over de voorbereiding op de beroepspraktijk van hun opleiding.

Zoals gezegd, worden in deze paragraaf de additionele kwalificaties besproken, die vóór of tijdens de studie zijn behaald. Deze kunnen verband houden met de genoten vooropleiding, de opgedane werkervaring en bestuurlijke ervaring en de eventueel gelopen stage.

\section{Vooropleiding}

Tabel 5.1 geeft een beeld van de hoogste met diploma voltooide vooropleiding alvorens men economie is gaan studeren. Naar voren komt dat de overgrote meerderheid $(77 \%)$ rechtstreeks vanuit het VWO is ingestroomd. Eén op iedere vijf afgestudeerden (19\%) heeft eerst een HBO-opleiding voltooid alvorens een economische opleiding aan de universiteit te gaan volgen. Dit is evenveel als bij de vorige enquête (19\%) en iets meer dan bij de daaraan voorafgaande enquête (17\%). Tabel 5.1 laat verder zien dat econometristen relatief het vaakst vanuit het VWO instromen en afgestudeerden IM vanuit het $\mathrm{HBO}$. 


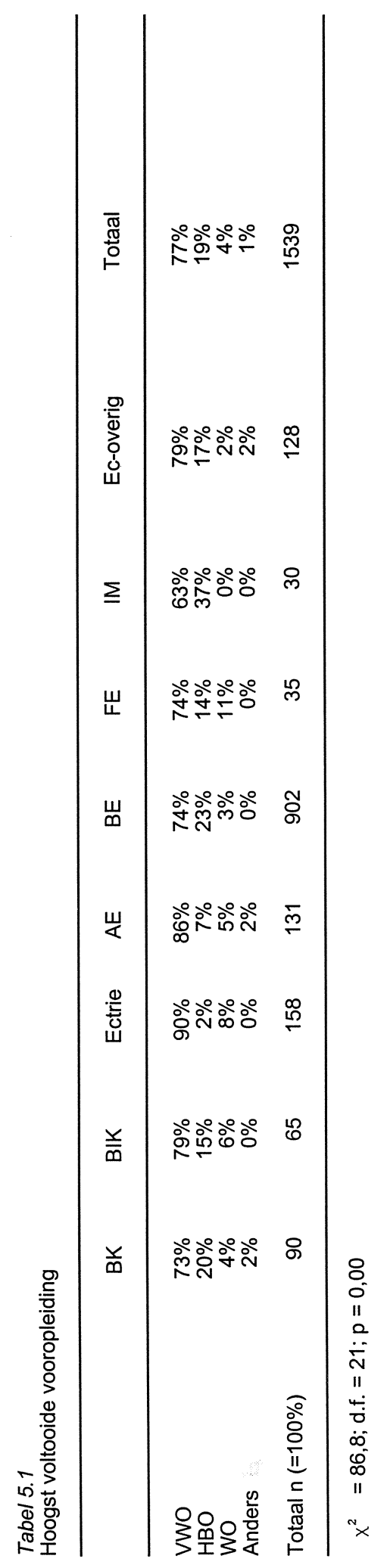




\section{Werkervaring}

Aan de afgestudeerden is gevraagd of zij vóór of tijdens de economie-studie betaalde of onbetaalde werkervaring (exclusief stages) hebben opgedaan die relevant is voor hun vakgebied. Dit blijkt bij de helft $(51 \%)$ van de afgestudeerden het geval te zijn (tabel 5.2). Dit is iets lager dan de $54 \%$ bij de vorige enquête, maar aanzienlijk hoger dan de $44 \%$ bij de voorlaatste enquête.

Stage ervaring

Twee van de drie economen (66\%; vorige meting eveneens $66 \%$ ) heeft tijdens de opleiding stage gelopen. Afgestudeerden IM hebben het vaakst stage gelopen en fiscaal economen het minst vaak (tabel 5.2).

\section{Bestuurlijke ervaring}

In de enquête is ook gevraagd of men vóór of tijdens de economie-studie bestuurlijke ervaring heeft opgedaan. Tabel 5.2 laat zien dat ruim de helft (57\%) op het moment van afstuderen over enigerlei vorm van bestuurlijke ervaring beschikt. Afgestudeerden IM beschikken het vaakst over bestuurlijke ervaring. Bij de vorige enquête bedroeg het aandeel met bestuurlijke ervaring $58 \%$ en het jaar daarvoor $60 \%$. Het aandeel van afgestudeerde economen met bestuurlijke ervaring neemt dus af.

\subsection{Na het afstuderen opgedane extra kwalificaties}

In deze paragraaf worden de additionele onderwijskwalificaties besproken die na het afstuderen eventueel zijn behaald. Deze kunnen verband houden met de deelname aan verder regulier onderwijs en bijscholing (cursorisch onderwijs en bedrijfsopleidingen).

\section{Regulier vervolgonderwijs}

Tabel 5.3 laat zien dat één op iedere acht afgestudeerde economen (12\%) een postdoctorale beroepsopleiding gaat volgen; $3 \%$ stroomt door naar een tweede faseopleiding, hetzij voor onderzoeker (afgerond 3\%) hetzij voor leraar (afgerond 1\%), en $5 \%$ neemt na het afstuderen gedurende kortere of langere tijd deel aan een andere opleiding. Bedrijfseconomen volgen vaker dan anderen een post-doctorale beroepsopleiding (vooral de postdoctorale beroepsopleiding accountancy), econometristen een tweede fase-opleiding en afgestudeerden BIK een andere opleiding (vooral een masters-opleiding). Afgestudeerden BK en IM volgen minder vaak verder onderwijs dan andere afgestudeerden. 


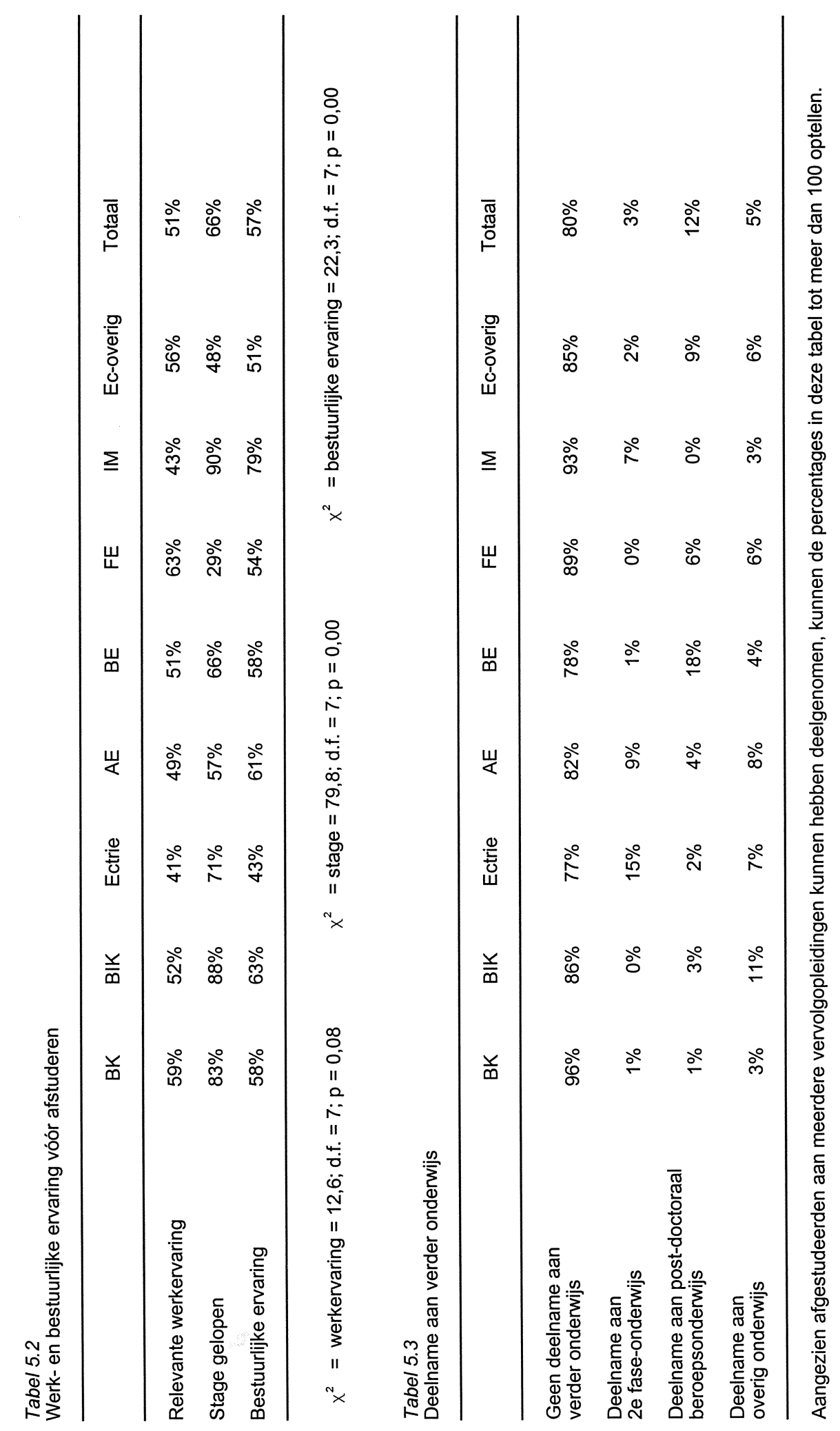


Per saldo heeft één op iedere vijf afgestudeerden (20\%) na het afstuderen gedurende kortere of langere tijd deelgenomen aan verder onderwijs. Dit is nagenoeg gelijk aan de $21 \%$ in de vorige meting en iets meer dan de $18 \%$ in de daaraan voorafgaande enquête. Overigens wordt de deelname aan verder onderwijs doorgaans gecombineerd met betaald werk als belangrijkste bezigheid. Op het moment van de enquête heeft 'slechts' $2 \%$ studie als belangrijkste bezigheid (tabel 2.4 ).

\section{Bijscholing}

Bijna de helft (47\%) van alle afgestudeerden heeft behoefte aan bijscholing. Dit is iets meer dan de $44 \%$ bij de vorige enquête en nagenoeg gelijk aan de $46 \%$ het jaar daarvoor. De behoefte aan bijscholing is het laagst onder fiscaal economen.

In tabel 5.4 komt verder naar voren dat ruim de helft (55\%) van alle afgestudeerden daadwerkelijk heeft deelgenomen aan bijscholing ${ }^{2}$. Dit is beduidend hoger dan de $45 \%$ in de vorige enquête. Afgestudeerden BIK volgen beduidend vaker bijscholing dan afgestudeerden van andere economische opleidingen.

De drie belangrijkste aanbieders van bijscholingsursussen zijn de eigen werkgever (36\%), bedrijfstakorganisaties (21\%) en partikuliere opleidingsinstituten (19\%). In de vorige enquête bedroegen hun aandelen respectievelijk $28 \%, 12 \%$ en $43 \%$. De resterende cursussen worden verzorgd door universiteiten ( $6 \%$, vorige meting $9 \%$ ), hogescholen ( $1 \%$, vorige meting $2 \%$ ) of door andere aanbieders $(17 \%$, vorige meting $6 \%)$. Er lijkt dus een verschuiving te zijn van partikuliere opleidingsinstituten naar bedrijfstakorganisaties, werkgevers en andere aanbieders van cursussen.

De eigen werkgever verzorgt het vaakst de bijscholing van afgestudeerden IM $(40 \%)$, BE (38\%), BIK (38\%), Economie-overig (36\%), econometrie (33\%) en AE $(31 \%)$. Bedrijfstakorganisaties verzorgen het vaakst de bijscholing van fiscaal economen (48\%) en bedrijfskundigen (40\%).

\subsection{Afstemming tussen opleiding en werk}

In tabel 3.4 zijn de belangrijkste beroepen genoemd die door pas afgestudeerde economen worden uitgeoefend. In deze paragraaf wordt eerst aangegeven hoe pas afgestudeerde economen de aansluiting tussen hun opleiding en hun werk beoordelen. Vervolgens wordt nagegaan welke specifieke kwalificaties van belang zijn bij hun beroepsuitoefening en in hoeverre deze kwalificaties voldoende aan bod zijn gekomen tijdens hun opleiding. De paragraaf wordt afgesloten met hun algemene beoordeling van de voorbereiding op de beroepspraktijk van hun opleiding.

2. Aan de faculteiten is via de faculteitsrapportage doorgegeven welke aanvullende opleidingen en cursussen door de afgestudeerden zijn gevolgd. 


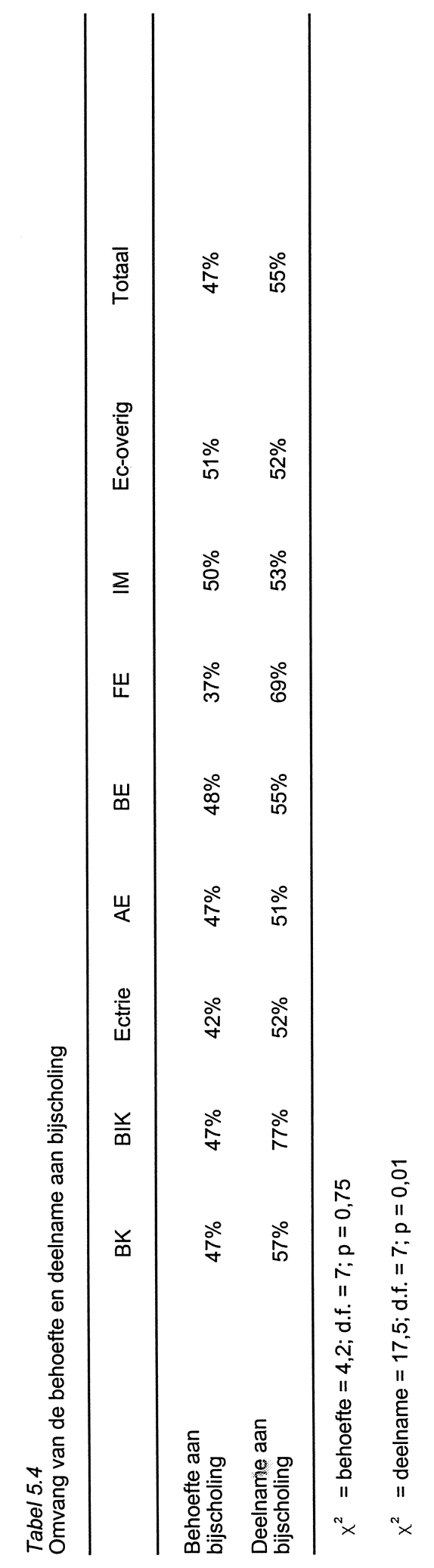




\section{Algemeen oordeel over de aansluiting tussen opleiding en werk}

De overgrote meerderheid ( $80 \%)$ van de betaald-werkende afgestudeerden beoordeelt de aansluiting tussen de door hen gevolgde economie-opleiding en het werk dat zij ten tijde van de enquête uitoefenen als goed of voldoende. Vorig jaar was $83 \%$ tevreden over de aansluiting tussen opleiding en werk. Het jaar daarvoor bedroeg het percentage 82 .

Afgestudeerden van de opleiding FE (97\%) zijn vaker tevreden over de aansluiting tussen hun opleiding en hun werk dan afgestudeerden van de opleidingen IM (89\%), BIK $(82 \%)$, BE (81\%), Econometrie (78\%), BK $(77 \%)$, AE (74\%) en Economie-overig $(72 \%)$.

\section{Kwalificaties}

Hieronder staan eventuele inhoudelijke discrepanties tussen het genoten economieonderwijs en het uitgeoefende werk centraal. Hiervan is sprake wanneer de kwalificaties die in het onderwijs worden bijgebracht niet passen bij de kwalificaties die worden vereist vanuit het werkveld. Het is daarbij van belang om op te merken dat hier uitsluitend het oordeel van de afgestudeerden aan bod komt. Dit hoeft niet overeen te stemmen met het oordeel vanuit het werkveld.

Voor het achterhalen van eventuele inhoudelijke discrepanties is aan de betaaldwerkende afgestudeerden een lijst van 26 kwalificatie-aspecten voorgelegd, die voor een goede uitoefening van hun functie van belang kunnen zijn. Hiertoe behoort één kwalificatie-aspect dat voor economie-opleidingen irrelevant is en waarover in deze rapportage derhalve niet wordt gerapporteerd ${ }^{3}$. De kwalificatie-aspecten zijn zo geformuleerd dat zij voor mensen uit verscheidene werkvelden toepasbaar zijn.

Bij elk kwalificatie-aspect konden de oudstudenten eerst aangegeven in hoeverre zij het genoemde aspect van belang achten voor een goede vervulling van hun huidige werkzaamheden en vervolgens of in de door hen gevolgde opleiding meer, evenveel of minder aandacht aan dit aspect moet worden besteed (vergeleken met de hoeveelheid aandacht die het desbetreffende kwalificatie-aspect tijdens hun opleiding heeft gekregen). In deze paragraaf worden de resultaten over beide vragen in hun onderlinge samenhang besproken. Het is immers goed mogelijk dat afgestudeerden bepaalde aspecten weliswaar van groot belang achten voor het goed functioneren in de beroepspraktijk, maar dat zij desondanks niet vinden dat de faculteit aan dit aspect meer aandacht moet gaan besteden dan tijdens hun opleiding het geval was. Het moge duidelijk zijn dat bepaalde houdingsaspecten, hoe

3. Het betreft het aspect 'fysieke vaardigheden, handvaardigheden, motoriek'. 
belangrijk wellicht ook in een functie, slechts gedeeltelijk kunnen worden aangeleerd tijdens een universitaire studie.

De onderzochte kwalificatie-aspecten verwijzen naar eisen ten aanzien van kennis, vaardigheden en houdingen, die onder meer zijn ontleend aan literatuur over functieanalyse (zie o.a. Algera, 19914). Deze aspecten lopen uiteen van vakkennis, inzicht in bedrijfsvoering en het plannen, organiseren en coördineren van activiteiten tot en met sociale vaardigheden zoals leidinggevende vaardigheden en contactuele vaardigheden, en aspecten ten aanzien van de werkhouding zoals aanpassingsvermogen en loyaliteit. Zoals eerder gezegd, zijn de aspecten zo geformuleerd dat zij voor mensen uit verscheidene werkvelden toepasbaar zijn.

Tabel 5.5 geeft een beeld van het belang voor de beroepsuitoefening van de onderscheiden kwalificaties en het oordeel of de betreffende kwalificaties in de opleiding voldoende aan bod zijn gekomen.

In de vorige enquêtes konden de afgestudeerden op een vierpuntsschaal aangeven in welke mate zij kwalificatie-aspecten belangrijk vonden voor een goede uitoefening van hun beroep. Om meer nuancering in de antwoorden mogelijk te maken, is thans gekozen voor een vijfpuntsschaal. In tabel 5.5 staat in de kolom 'belang' voor ieder aspect het percentage betaald-werkende afgestudeerden dat het betreffende aspect belangrijk of zeer belangrijk vindt voor een goede uitoefening van de functie. Door het overstappen van een vier- op een vijfpuntsschaal kan het voorkomen dat de percentages dit jaar lager zijn dan in de voorafgaande jaren.

Uit tabel 5.5 blijkt dat alle genoemde kwalificatie-aspecten, behoudens inzicht in wettelijke regelingen op het eigen vakgebied, taalvaardigheid (actieve en passieve beheersing van vreemde talen), leidinggeven en pedagogisch-didactische vaardigheden door de meerderheid van pas afgestudeerde economen belangrijk worden geacht voor het vervullen van de functie. De genoemde aspecten zijn blijkbaar in hoge mate relevant voor het typeren van de kwalificaties die de afgestudeerde economen bij hun arbeidsmarktintrede nodig hebben. Bij 12 van de 25 aspecten vindt zelfs tenminste driekwart van de betaald-werkende afgestudeerden dat dit aspect belangrijk is voor een goede uitoefening van de functie. Door de bank genomen vinden afgestudeerden een juiste werkhouding belangrijker voor het goed kunnen functioneren in het werk dan vaardigheden en kennis \& technieken.

Bij een aantal aspecten manifesteren zich significante verschillen tussen de opleidingen wat het belang voor de beroepsuitoefening betreft. Zo vinden afgestudeerden BIK inzicht in informatie- \& communicatietechnologie ( $93 \%$ tegen gemiddeld $76 \%$ ),

4. Algera, J.A. (redactie, 1991), Analyse van arbeid vanuit verschillende perspectieven, Swets \& Zeitlinger, Amsterdam/Lisse. 
Tabel 5.5

Afstemming tussen onderwijs en beroepspraktijk

$\begin{array}{ll}\text { Belangrijk } & \text { Meer aandacht } \\ \text { in praktijk } & \text { nodig }\end{array}$

\section{Kennis en technieken}

vakkennis

vakspecifieke methoden en technieken

recente ontwikkelingen in het vakgebied

inzicht in informatie- \& communicatietechnologie

inzicht in wettelijke regelingen eigen vakgebied

inzicht in bedrijfsvoering (organ/financ/admin)

praktijk

aandacht

\section{Vaardigheden}

toepassen kennis \& technieken in de praktijk

analytische en diagnostische (onderzoeks)vaardigheden

kwantitatieve (onderzoeks)vaardigheden

taalvaardigheid (beheersing vreemde talen)

schriftelijke presentatie, schrijfvaardigheid

mondelinge presentatie, spreekvaardigheid

onderhandelingstechnische en commerciële vaardigheden

plannen, coördineren, organiseren activiteiten

verzamelen/documenteren informatie, gegevensbeheer

leidinggeven

pedagogisch-didactische vaardigheden

contactuele vaardigheden

$\begin{array}{ll}71 \% & 18 \% \\ 66 \% & 24 \% \\ 69 \% & 41 \% \\ 76 \% & 53 \% \\ 46 \% & 23 \% \\ 71 \% & 32 \%\end{array}$

\section{Houdingsaspecten}

zelfstandigheid

initiatief, creativiteit

aanpassingsvermogen

functioneren onder werkdruk

- nauwkeurigheid, zorgvuldigheid

- loyaliteit, integriteit

- $\quad$ systematische reflectie, terugkoppeling, feedback

$69 \% \quad 48 \%$

$65 \% \quad 27 \%$

$70 \% \quad 19 \%$

$50 \% \quad 39 \%$

$81 \% \quad 52 \%$

$86 \% \quad 64 \%$

$70 \% \quad 62 \%$

$78 \% \quad 44 \%$

$63 \% \quad 23 \%$

$38 \% \quad 33 \%$

$49 \% \quad 30 \%$

$89 \%-45 \%$

$93 \% \quad 18 \%$

$\begin{array}{ll}91 \% & 38 \% \\ 86 \% & 20 \%\end{array}$

$89 \% \quad 26 \%$

$88 \% \quad 19 \%$

$82 \% \quad 35 \%$

$77 \% \quad 30 \%$

plannen/coördineren/ organiseren van activiteiten (93\% tegen gemiddeld $78 \%$ ) en loyaliteit/integriteit ( $97 \%$ tegen gemiddeld $82 \%$ ) belangrijker voor een goede beroepsuitoefening dan afgestudeerden van de andere opleidingen. Van alle afgestudeerden vinden econometristen analytische vaardigheden $(76 \%$ tegen gemiddeld $65 \%$ ) en kwantitatieve (onderzoeks)vaardigheden ( $80 \%$ tegen gemiddeld $70 \%$ ) het belangrijkst. Belangrijker dan andere afgestudeerden vinden fiscaal economen vakkennis $(91 \%$ tegen gemiddeld $71 \%)$, vakspecifieke methoden \& technieken $(91 \%$ tegen gemiddeld $66 \%)$, recente ontwikkelingen binnen het vakgebied $(94 \%$ tegen gemiddeld $69 \%$ ), inzicht in wettelijke regelingen op het eigen vakgebied $(91 \%$ tegen gemiddeld $46 \%$ ), de praktische toepassing van kennis ( $91 \%$ tegen gemiddeld $69 \%$ ), schriftelijke vaardigheden ( $97 \%$ tegen gemiddeld $81 \%$ ) en onderhandelingstechnische en commerciële vaardigheden ( $88 \%$ tegen gemiddeld $70 \%)$. Voor afgestudeerden IM, tenslotte, is inzicht in bedrijfsvoering ( $80 \%$ tegen gemiddeld $71 \%)$ belangrijker dan voor andere afgestudeerden. 
Door het volgen van opleidingen moeten mensen dié kwalificaties leren die nodig zijn om meer of minder gespecialiseerde arbeidsprestaties te kunnen leveren. Vanuit de arbeidsmarkt bezien, moet een opleiding derhalve in de juiste mate aandacht besteden aan kwalificaties die van belang zijn voor een goede beroepsuitoefening. Daarom is nagegaan of de genoemde kwalificatie-aspecten tijdens de opleiding wel voldoende aan bod zijn gekomen volgens de afgestudeerden. Het is overigens nog maar de vraag of juist tijdens de economie-opleiding meer aandacht moet en kan worden geschonken aan bijvoorbeeld de juiste houdingsaspecten, die zo belangrijk blijken te zijn.

De betaald-werkende afgestudeerden konden in de vragenlijst per aspect aangeven of hieraan tijdens de door hen gevolgde opleiding meer, evenveel of minder aandacht moet worden besteed. Hierbij moet worden opgemerkt dat afgestudeerden zich niet altijd realiseren dat meer aandacht voor het ene aspect, bij een gelijkblijvende studieduur, minder aandacht voor een ander aspect betekent.

Wanneer de resultaten over het belang van de kwalificaties in de beroepspraktijk worden vergeleken met de resultaten over de benodigde aandacht hiervoor, valt op dat de kwalificatie-aspecten die het vaakst van belang blijken te zijn bij het uitoefenen van de functie, niet altijd de aspecten zijn waaraan volgens de afgestudeerden meer aandacht zou moeten worden besteed tijdens de economie-opleiding. Terwijl bijvoorbeeld $93 \%$ van de betaald-werkende economen van mening is dat zelfstandigheid van belang is voor het goed kunnen functioneren in de functie, vindt 'slechts' $18 \%$ dat er tijdens de economie-opleiding meer aandacht moet zijn voor dit aspect. Dit laat onverlet dat er ook houdingsaspecten zijn waarvoor wel relatief vaak meer aandacht wordt gevraagd, bijvoorbeeld voor initiatief, creativiteit.

Uit tabel 5.5 blijkt verder dat meer dan de helft van de betaald-werkende economen meer aandacht nodig acht voor inzicht in informatie- \& communicatietechnologie, schriftelijke en mondelinge presentatie/vaardigheden en onderhandelingstechnische en commerciële vaardigheden. Dit betekent dat er tijdens de economie-opleiding meer ruimte zou moeten zijn voor training op deze terreinen, hetzij in aanvullende lessen (in het geval van inzicht in informatie- \& communicatietechnologie), hetzij door een andere vormgeving van het bestaande onderwijs (in het geval van mondeling en schriftelijk presenteren en onderhandelingstechnische en commerciële vaardigheden). Ook stages lenen zich goed voor het aanleren van dergelijke vaardigheden. De faculteiten zouden ook nascholingscursussen op deze terreinen kunnen aanbieden.

Met betrekking tot de kennis en vaardigheden die direct verband houden met het vakgebied economie zou de faculteit zich volgens de afgestudeerden vooral meer moeten richten op de praktische toepassingsmogelijkheden van de vakkennis en op de actualiteit daarvan. Aan de vakkennis zelf wordt naar de mening van de afgestu- 
deerden voldoende aandacht besteed: hoewel $71 \%$ vakkennis belangrijk vindt voor het goed kunnen uitoefenen van de functie, is 'slechts' $18 \%$ van mening dat hieraan tijdens de economie-opleiding meer aandacht zou moeten worden besteed.

Bij 11 aspecten manifesteren zich significante verschillen tussen de opleidingen wat de gewenste aandacht betreft. Zo zouden bedrijfskundigen vaker dan andere afgestudeerden (behoudens afgestudeerden IM) meer aandacht willen besteden aan het functioneren onder werkdruk (33\% tegen gemiddeld $26 \%$ ) en afgestudeerden BIK aan het bijhouden van recente ontwikkelingen in het vakgebied $(64 \%$ tegen gemiddeld $41 \%$ ) en mondeling presenteren (76\% tegen gemiddeld $64 \%$ ). Afgestudeerden $\mathrm{AE}$ zouden vaker dan andere afgestudeerden meer aandacht willen besteden aan analytische vaardigheden (44\% tegen gemiddeld $27 \%$ ) en kwantitatieve vaardigheden (30\% tegen gemiddeld $19 \%)$. Vaker dan anderen wensen fiscaal economen meer aandacht voor vakspecifieke methoden en technieken ( $46 \%$ tegen gemiddeld $24 \%$ ), de praktische toepassing van kennis ( $71 \%$ tegen gemiddeld $48 \%$ ) en schriftelijk presenteren (74\% tegen gemiddeld $52 \%$ ). Afgestudeerden IM, tenslotte, wensen vaker dan anderen meer aandacht voor inzicht in informatie- \& communicatietechnologie ( $74 \%$ tegen gemiddeld $53 \%$ ), inzicht in bedrijfsvoering $(54 \%$ tegen gemiddeld $32 \%$ ), onderhandelingstechnische en commerciële vaardigheden $(75 \%$ tegen gemiddeld $62 \%$ ) en het functioneren onder werkdruk $(33 \%$ tegen gemiddeld $26 \%$ ). Kortom, de leemten in kennis en vaardigheden die pas afgestudeerde economen ervaren, variëren met de kwalificaties die zij tijdens hun opleiding hebben verworven (geïndiceerd door de gevolgde opleidingsrichting).

\section{Algemeen oordeel over de voorbereiding op de beroepspraktijk}

Aan de afgestudeerden is gevraagd om de voorbereiding van hun opleiding op de beroepspraktijk te beoordelen met behulp van een 'rapportcijfer' (een afgerond cijfer, variërend van 1 tot 10). Gebleken is dat de betaald-werkende afgestudeerden door de bank genomen slechts matig tevreden zijn over deze voorbereiding op de beroepspraktijk (een gemiddeld rapportcijfer van 'slechts' 5,8). De hierbij gevonden standaardafwijking van 1,4 betekent echter dat de verschillen in beoordeling tussen afgestudeerden tamelijk groot zijn.

Fiscaal economen zijn nog het meest tevreden over hun voorbereiding op de beroepspraktijk (gemiddeld rapportcijfer van 6,4), gevolgd door afgestudeerden IM $(6,3)$, BIK $(6,1)$ en $B K(6,1)$. lets minder tevreden zijn econometristen $(5,9)$ en afgestudeerden $B E(5,8)$. Het minst tevreden wat dit aspect van de opleiding betreft zijn afgestudeerden $\mathrm{AE}(5,5)$ en Economie-overig $(5,5)$. 


\section{Opleiding achteraf bezien}

\subsection{Oordeel over de opleiding}

In dit hoofdstuk worden eerst de gemiddelde 'rapportcijfers' gepresenteerd die door de afgestudeerden aan een vijftal aspecten van hun opleiding zijn toegekend, alsmede hun oordeel over de moeilijkheidsgraad en de mate van specialisatie van hun opleiding. Vervolgens wordt ingegaan op de vraag of de afgestudeerden, achteraf bezien, opnieuw dezelfde opleiding zouden kiezen.

Aan alle afgestudeerden, dus ook degenen die niet betaald-werken, is gevraagd om een 'rapportcijfer' (een afgerond cijfer, variërend van 1 tot 10) te geven aan elk van de zes hieronder genoemde opleidingsaspecten:

- de samenhang tussen de vakken;

- de keuzemogelijkheden in de studie;

- de studiebegeleiding;

- de kwaliteit van de docenten;

- de voorbereiding op de beroepspraktijk;

- de voorlichting over de arbeidsmarktsituatie.

Aangezien het aspect 'voorbereiding op de beroepspraktijk' reeds in paragraaf 5.3 aan bod is gekomen, worden in tabel 6.1 de gemiddelde 'rapportcijfers' weergegeven van de vijf overige opleidingsaspecten. Naar voren komt dat de keuzemogelijkheden in het studieprogramma het beste worden beoordeeld, gevolgd door de samenhang in het vakkenpakket en de kwaliteit van het docentenkorps. Minder goed te spreken zijn de afgestudeerden over de begeleiding tijdens hun studie en de voorlichting over de arbeidsmarkt. Tabel 6.1 laat verder zien dat verschillen tussen de opleidingen zich vooral manifesteren bij de keuzemogelijkheden in de opleiding, de kwaliteit van het docentenkorps en de voorlichting over de arbeidsmarkt. Afgestudeerden IM, AE en BE blijken meer dan gemiddeld tevreden te zijn over de keuzemogelijkheden in hun opleiding en afgestudeerden FE over de kwaliteit van de docenten en de arbeidsmarktvoorlichting.

Aan de afgestudeerden is gevraagd of de moeilijkheidsgraad van de gevolgde opleiding naar hun mening precies goed, niet hoog genoeg of wellicht te hoog is. Hen is ook gevraagd of de opleiding naar hun mening te specialistisch is, of dat de mate van specialisatie van de opleiding precies voldoende danwel onvoldoende is. Tabel 6.2 laat zien dat de mate waarin de opleiding is gespecialiseerd en de zwaarte van de opleiding volgens de meeste afgestudeerden niet hoeven te worden bijgesteld. Dit laat onverlet dat nog altijd een op de vijf afgestudeerden vindt dat de opleiding meer gespecialiseerd zou moeten zijn. Een opmerkelijk resultaat is verder dat maar liefst $28 \%$ van de afgestudeerden van mening is dat de opleiding zwaarder 
zou mogen worden, terwijl slechts $2 \%$ zegt dat de opleiding minder zwaar zou moeten zijn.

\subsection{Studiekeuze achteraf bezien}

In deze paragraaf komt de vraag aan de orde of de afgestudeerden achteraf bezien opnieuw dezelfde opleiding zouden kiezen. Het antwoord op deze vraag kan worden beschouwd als een indicatie van hun algemeen oordeel over de gevolgde economie-opleiding.

Tabel 6.3 laat zien dat veruit de meeste (86\%) afgestudeerde economen achteraf blij zijn met de destijds gemaakte studiekeuze: zij zouden opnieuw voor dezelfde opleiding aan dezelfde universiteit kiezen $(78 \%)$ of voor dezelfde opleiding maar dan aan een andere universiteit ( $8 \%)$. Eén op zeven (14\%) betreurt de destijds genomen studiekeuze: zij zouden, achteraf bezien, een andere academische opleiding hebben gekozen $(11 \%)$, een niet-universitaire opleiding zijn gaan volgen $(2 \%)$ of niet zijn gaan studeren maar bijvoorbeeld direct zijn gaan werken (1\%). Tabel 6.2 laat verder zien dat afgestudeerden $\mathrm{AE}$ en IM iets vaker dan gemiddeld achteraf een andere academische opleiding zouden hebben gekozen.

Als alternatieve opleiding voor de destijds gekozen opleiding, wordt het vaakst een niet-economische academische opleiding genoemd (46\%), gevolgd door een andere economische academische opleiding (39\%) en een HBO-opleiding (15\%).

De tevredenheid van afgestudeerde economen over hun studiekeuze neemt overigens toe: het aantal spijtoptanten is gedaald van $19 \%$ in meting '94 naar $18 \%$ in meting '95 tot $14 \%$ in meting ' 96 . 


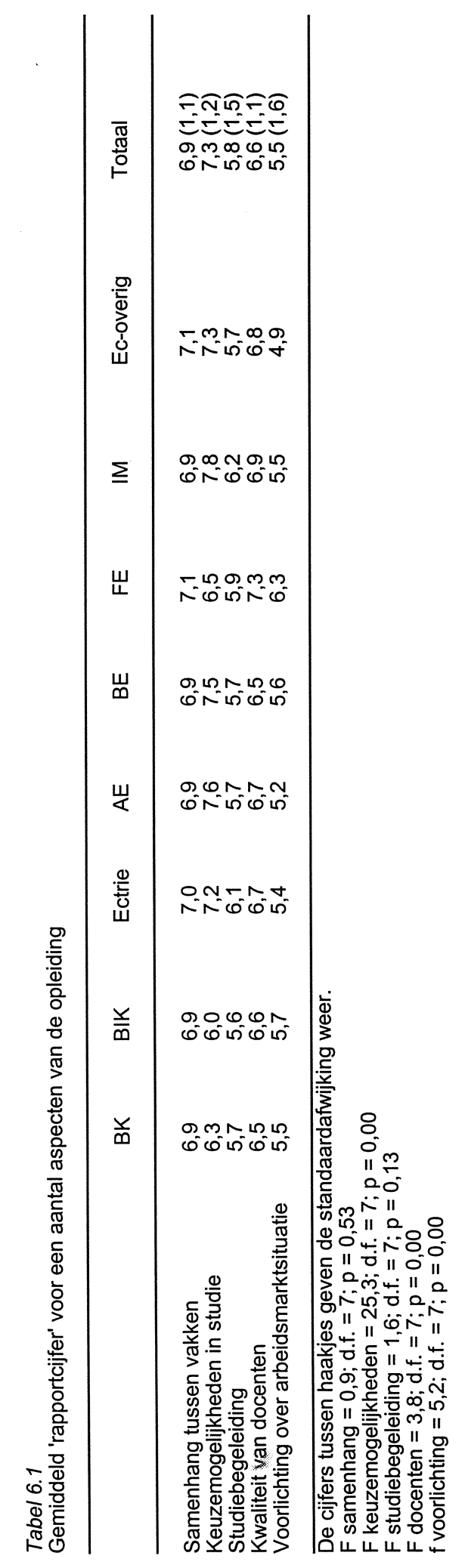




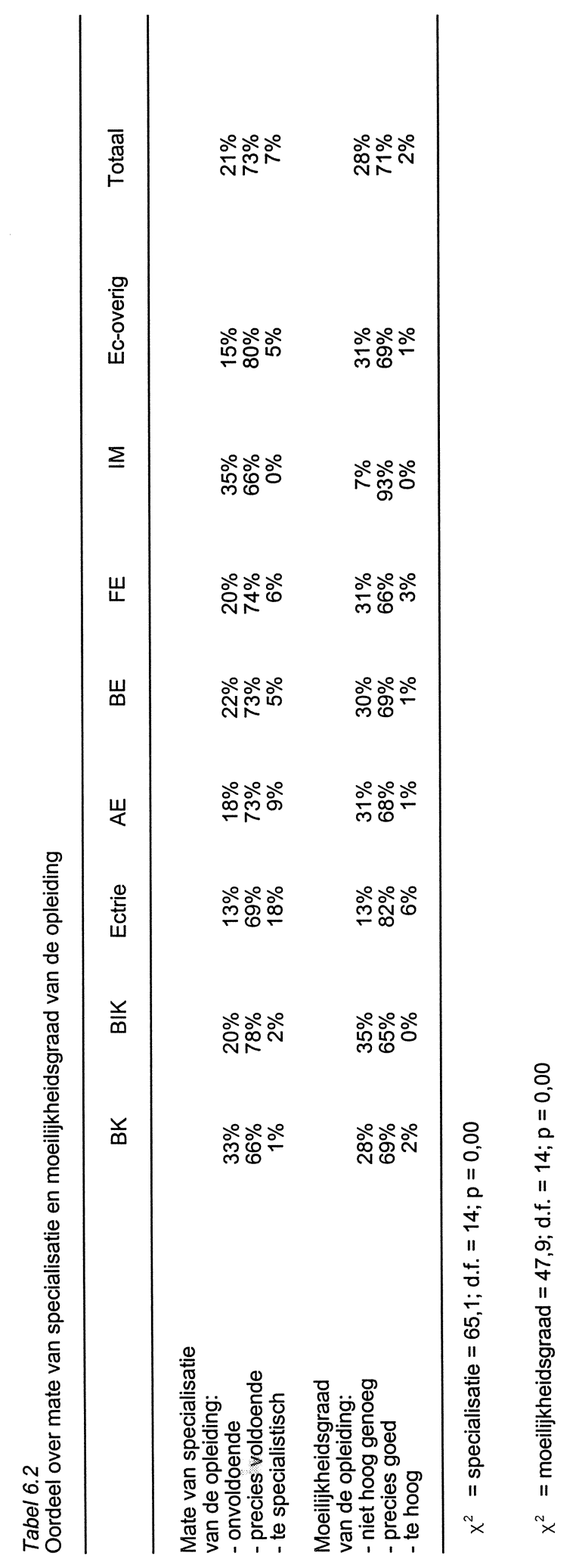




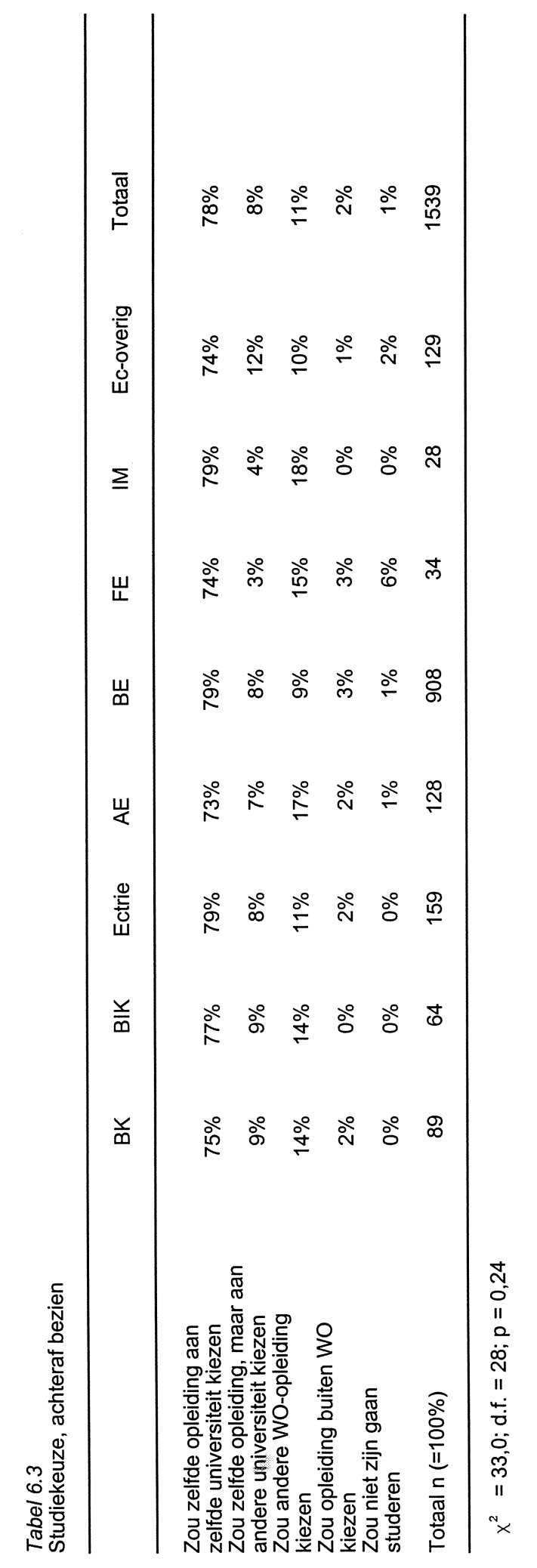




\section{Thema: Mobiliteit bij de intrede op de arbeidsmarkt}

In dit hoofdstuk wordt eerst nagegaan of men verhuisd is van de provincie waar men heeft gestudeerd naar de provincie waar men ten tijde van de enquête werkt (geografische mobiliteit). Vervolgens wordt aangegeven of men na het afstuderen al eens van baan is veranderd (baanmobiliteit). In aansluiting daarop wordt nagegaan of verandering van baan al dan niet een verbetering inhoudt.

\section{Geografische mobiliteit}

Geografische mobiliteit duidt op de bereidheid van afgestudeerden om voor een baan te verhuizen of te pendelen. Daarnaast zegt geografische mobiliteit iets over de werkgelegenheidssituatie in de eigen regio: bij onvoldoende geschikte banen in de eigen regio zijn afgestudeerden namelijk genoodzaakt om banen verder van huis te accepteren. Met eigen regio wordt hier bedoeld de provincie waar men heeft gestudeerd of een daaraan grenzende provincie.

In dit rapport is sprake van geografische mobiliteit wanneer men werkt in een provincie die niet grenst aan de provincie waar de universiteit is gesitueerd, of wanneer men in het buitenland werkt. Aldus opgevat, is een vijfde (20\%) van de betaald-werkende economen geografisch mobiel. Vorig jaar was dit $23 \%$ en het jaar daarvoor $16 \%$. De geografische mobiliteit is dus ten opzichte van vorig jaar iets afgenomen. Tabel 7.1 laat zien dat van alle afgestudeerden oudstudenten BIK en IM het vaakst buiten de eigen regio gaan werken. Oudstudenten IM werken bovendien vaker dan gemiddeld in het buitenland.

\section{Baanmobiliteit}

De intrede op de arbeidsmarkt van afgestudeerden wordt gekenmerkt door het vaak veranderen van baan. Baanmatchtheorieën verklaren de hoge mate van baanmobiliteit in de beginfase van de loopbaan door onzekerheid en imperfecte informatie aan de kant van zowel de afgestudeerden als de werkgevers. Bij de afgestudeerden verwijst de term 'job-shopping' naar deze fase van experimenteren met banen. Werkgevers kijken steeds vaker eerst de kat uit de boom alvorens iemand een vaste aanstelling te geven. Het veelvuldig veranderen van baan is ook een gevolg van de toenemende tendens tot flexibilisering van arbeid waardoor afgestudeerden steeds vaker zijn aangewezen op tijdelijke banen, vaak onder het opleidingsniveau.

In de enquête is aan alle afgestudeerden gevraagd hoeveel betaalde banen men na het afstuderen heeft gehad (excl. de eventuele huidige baan en militaire/vervangende dienst. Uitzendperiodes moesten hierbij ieder afzonderlijk worden meegeteld. Tabel 7.2 laat zien dat, gemeten zo'n anderhalf jaar na het afstuderen, $41 \%$ van alle 


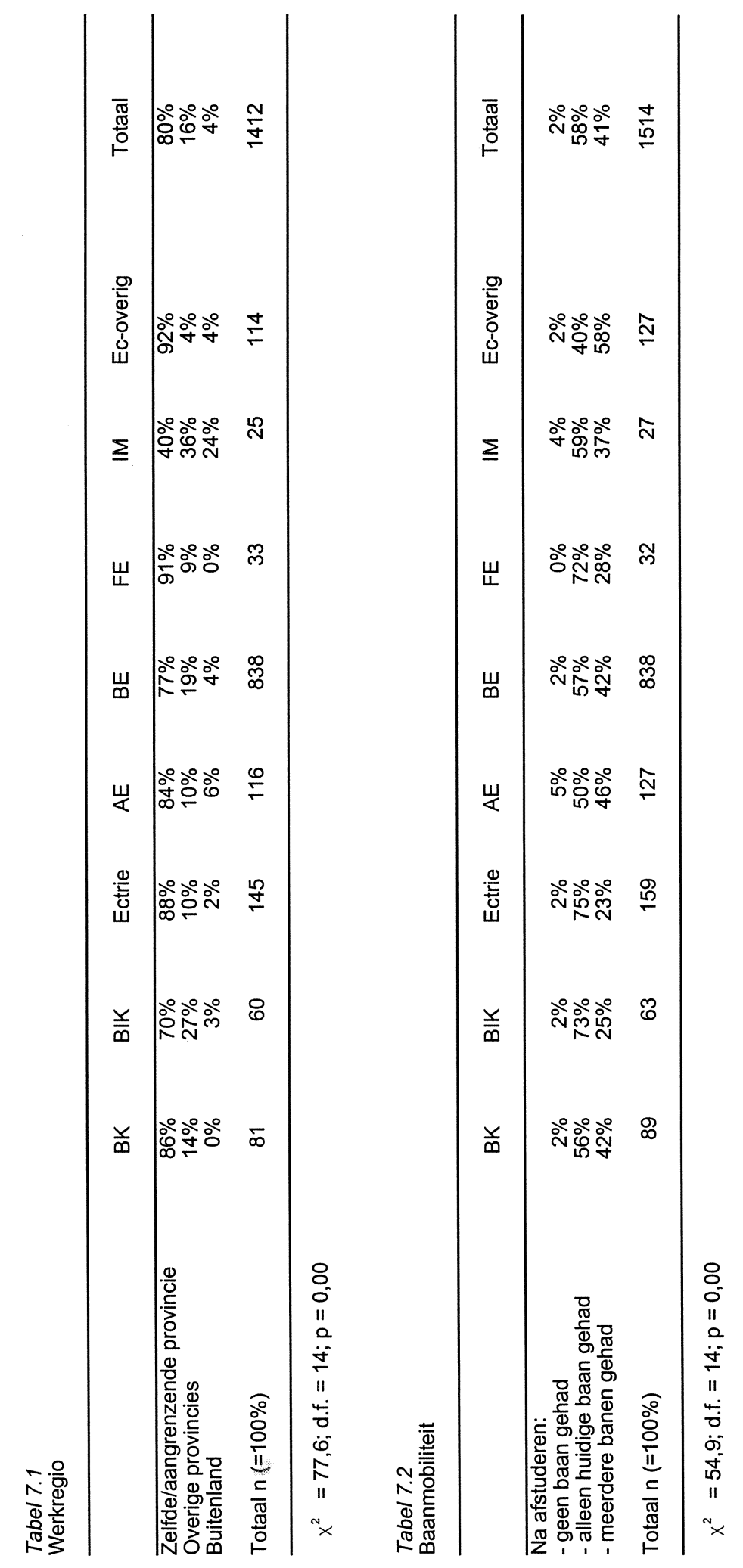


respondenten al eens van baan is veranderd: zij hebben na het afstuderen al meer dan één baan gehad. Van de betaald-werkende respondenten is $39 \%$ (vorig meetjaar $44 \%$ en de meting daarvoor $41 \%$ ) niet langer in de eerste baan werkzaam. Afgestudeerden Ec-overig en $A E$ zijn het vaakst al eens van baan veranderd, en afgestudeerden Econometrie, BIK en FE het minst vaak.

\section{Verandering in baanzekerheid}

Aan degenen die na het afstuderen meerdere banen hebben gehad, is ook gevraagd naar de soort aanstelling en het vereiste opleidingsniveau van hun eerste baan na afstuderen. Dit maakt het mogelijk om veranderingen in baanzekerheid en baanniveau tijdens het intredeproces in kaart te brengen.

Welnu, bijna de helft (47\%) van de betaald-werkende afgestudeerden start de loopbaan in een tijdelijke baan. lets meer dan de helft (53\%) heeft geluk: zij zijn meteen in een vaste baan kunnen beginnen. De zekerheid van de eerste baan is in hoge mate bepalend voor de baanmobiliteit in de eerste anderhalf jaar na het afstuderen. Degenen die de loopbaan starten in een tijdelijke baan veranderen (gemeten circa 18 maanden na afstuderen) veel vaker van baan dan degenen die de loopbaan in een vaste baan starten. Gemeten zo'n anderhalf jaar na het afstuderen is ruim de helft $(62 \%)$ van de starters in een tijdelijke baan van baan veranderd; van de starters in een vaste baan 'slechts' $14 \%$.

De veranderingen in baanzekerheid tijdens het intredeproces in relatie tot de baanmobiliteit worden als volgt in tabel 7.3 getypeerd (bij het operationaliseren van deze typologie zijn alleen intredebanen verdisconteerd die tenminste twee maanden hebben geduurd). De helft (51\%) van de betaald-werkende afgestudeerden start de loopbaan in een vaste baan en blijft in deze baan werken; $4 \%$ start in een vaste baan, verandert van baan en heeft thans opnieuw een vaste baan. Een op de tien afgestudeerden (10\%) weet de baanzekerheid te verbeteren: zij starten in een tijdelijke baan, veranderen van baan en hebben thans een vaste baan. Bij $3 \%$ verslechtert de loopbaan wat dit kenmerk betreft: zij beginnen weliswaar in een vaste baan maar veranderen van baan en hebben thans een tijdelijke baan. Een op de vijf afgestudeerden (20\%) start de loopbaan in een tijdelijke baan en werkt op het moment van de enquête nog steeds in deze tijdelijke baan. Tenslotte start $13 \%$ in een tijdelijke baan en blijft ook na verandering van baan afhankelijk van tijdelijke banen.

Gezien het bovenstaande kunnen oudstudenten in twee hoofdgroepen worden ingedeeld. In de eerste plaats afgestudeerden die, al dan niet na baanverandering, blijven werken in vaste banen (55\%) en afgestudeerden waarbij de baanzekerheid is toegenomen (10\%). Aan de andere kant afgestudeerden die, al dan niet na baanverandering, blijven aangewezen op tijdelijke banen (33\%) en afgestudeerden waarbij 


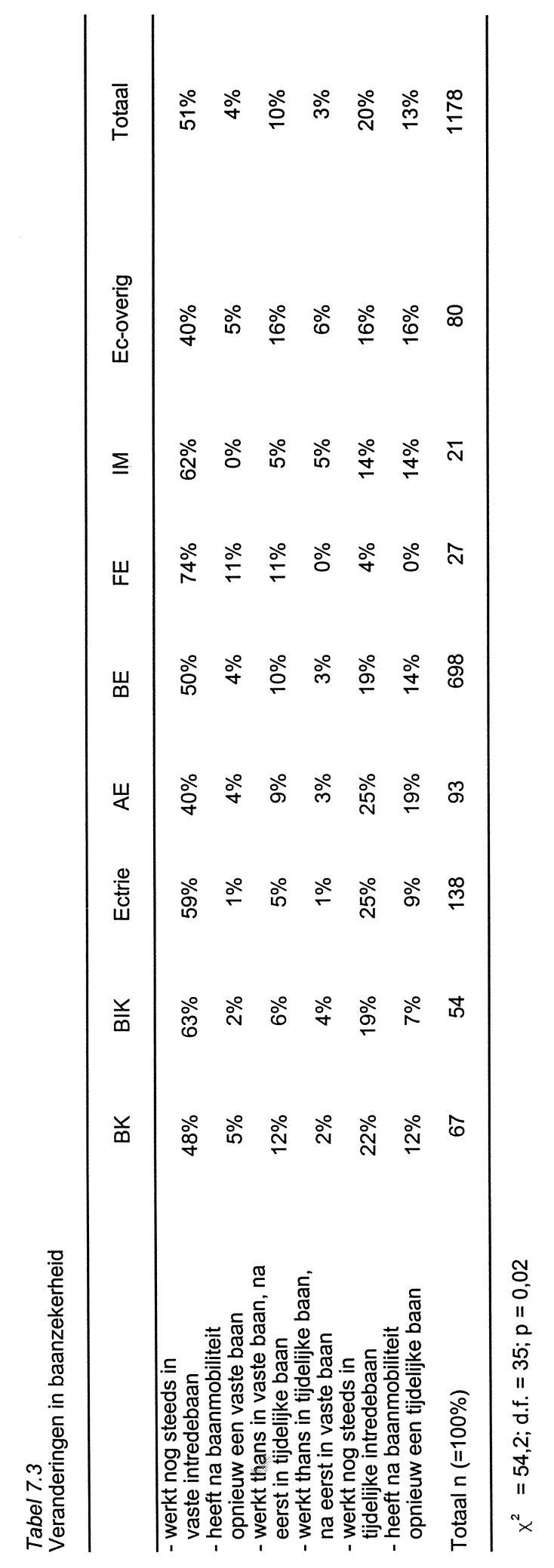


de baanzekerheid zelfs is afgenomen (3\%). De resultaten in tabel 7.3 laten zien dat fiscaal economen vaker dan anderen (al dan niet na baanverandering) blijven werken in vaste banen. Ook de toename van de baanzekerheid is bij fiscaal economen het grootst van alle afgestudeerden.

\section{Verandering in baanniveau}

Volgens de matchingtheorie ${ }^{5}$ resulteert de produktiviteit van individuen niet alleen uit de specifieke kennis en vaardigheden waarover zij beschikken maar ook uit de specifieke functie waarin deze kennnis en vaardigheden worden toegepast. In deze visie leidt mismatch tot produktiviteitsverlies. Dit is bijvoorbeeld het geval wanneer een universitair opgeleide werknemer een baan heeft waarvoor een opleiding op academisch niveau niet nodig is. Aan een baan onder het opleidingsniveau is derhalve een lager loon verbonden dan aan een baan die wel past bij het niveau van de genoten opleiding ${ }^{6}$. Aan verandering van baan, bijvoorbeeld ter opheffing van mismatch, zijn voor de werknemers transactiekosten verbonden, die zij zullen afwegen tegen het hogere loon dat zij bij een beter bij hun opleiding passende baan kunnen verdienen. In het onderstaande wordt ervan uitgegaan dat het hogere loon bij een goede match altijd opweegt tegen de transactiekosten in verband met mobiliteit. Op basis van het loonverlies door een mismatch tussen het opleidingsniveau en het niveau van de functie waarin men werkzaam is en het hogere loon dat men in een hogere functie zou kunnen verdienen, kan de volgende rangorde van loopbaanpatronen worden opgesteld, waaraan een afnemend loon is verbonden:

1 de afgestudeerde krijgt een qua niveau passende intredebaan, verandert van baan en krijgt opnieuw niveau-passend werk (geen vroeger loonverlies door mismatch, wel huidige loonwinst door mobiliteit);

2 de afgestudeerde krijgt een qua niveau passende intredebaan blijft in deze baan werken (geen loonverlies door mismatch en geen loonwinst door mobiliteit);

3 de afgestudeerde krijgt een intredebaan onder zijn niveau, verandert van baan en krijgt dan werk dat wel past bij zijn opleidingsniveau (vroeger loonverlies door mismatch en huidige loonwinst door mobiliteit);

4 de afgestudeerde krijgt een qua niveau passende intredebaan, verandert van baan en komt vervolgens onder zijn opleidingsniveau terecht (geen vroeger loonverlies door mismatch, loonwinst door mobiliteit, maar tevens loonverlies door mismatch);

5 de afgestudeerde krijgt een intredebaan onder zijn niveau, verandert van baan, maar komt opnieuw onder zijn niveau terecht (vroeger loonverlies door mismatch, loonwinst door mobiliteit, maar tevens huidig loonverlies door mismatch);

5. Voor een overzicht zie: Sattinger, M. (1993), Assignment Models of the Distribution of Earnings, Journal of Economic Literature, jaargang 31, nummer 2, blz. 851-880.

6. Zie ook: Hartog J. en H. Oosterbeek (1988), Education, allocation and earnings in the Netherlands: overschooling?, Economics of Education Review, jaargang 7, nummer 2, blz. 185-194. 
6 de afgestudeerde krijgt een intredebaan onder zijn niveau en blijt in deze baan werken (permanent loonverlies door mismatch, geen loonwinst door mobiliteit).

$\mathrm{Bij}$ het operationaliseren van deze typologie zijn alleen intredebanen verdisconteerd die tenminste twee maanden hebben geduurd.

Op basis van de kosten voor mismatch en mobiliteit kunnen de pas afgestudeerde economen worden ingedeeld in de volgende twee hoofdgroepen. In de eerste plaats afgestudeerden die, al dan niet na baanverandering, blijven werken in banen die passen bij het niveau van hun opleiding (45\%) en afgestudeerden waarbij de match tussen baanniveau en opleidingsniveau is verbeterd $(9 \%)$. Aan de andere kant afgestudeerden die, al dan niet na baanverandering, onder hun opleidingsniveau blijven werken (42\%) en afgestudeerden waarbij de match tussen baanniveau en opleidingsniveau zelfs is verslechterd $(5 \%)$. De resultaten in tabel 7.4 laten zien dat fiscaal economen vaker dan afgestudeerden van andere opleidingen blijven werken in qua niveau passende intredebanen en algemeen economen relatief vaak na baanverandering niveau-passend werk krijgen. Bij afgestudeerden van opleidingen die behoren tot de categorie Economie-overig kan worden geconstateerd dat de match tussen opleidingsniveau en functieniveau na baanverandering relatief het vaakst zowel verslechterd als verbeterd. Afgestudeerden BIK zijn vaker dan andere afgestudeerden nog steeds werkzaam in intredebanen onder hun opleidingsniveau. Bedrijfseconomen krijgen, relatief gezien, het vaakst na baanverandering opnieuw werk onder hun opleidingsniveau.

Zoals eerder reeds is opgemerkt, resulteert de produktiviteit van individuen volgens de baanmatchingtheorie zowel uit de specifieke kennis en vaardigheden waarover zij beschikken als uit de specifieke functie waarin deze kennnis en vaardigheden worden toegepast. De verwachting is dan ook dat het loon toeneemt naarmate de match tussen opleidingsniveau en functieniveau gedurende de intredeperiode beter is.

In de analyse van het loon in hoofdstuk 4 (tabel 4.3) komt naar voren dat afgestudeerden die (al dan niet na baanverandering) op hun niveau werken significant meer verdienen dan afgestudeerden die (al dan niet na baanverandering) onder hun opleidingsniveau werkzaam zijn. De hoogte van het loon blijkt dus niet, zoals verwacht, omgekeerd gerelateerd te zijn aan het totaal van de kosten voor mismatch en mobiliteit, maar in de eerste plaats bepaald te worden door het niveau van de baan en daarmee door de kosten voor mismatch. De analyseresultaten laten verder zien dat het loon bij een goede match na mobiliteit hoger is dan bij een goede match zonder mobiliteit. Het lijkt erop dat afgestudeerden alleen genegen zijn van baan te veranderen (en bijgevolg mobiliteitskosten te maken) indien hier extra loon tegenover staat. 


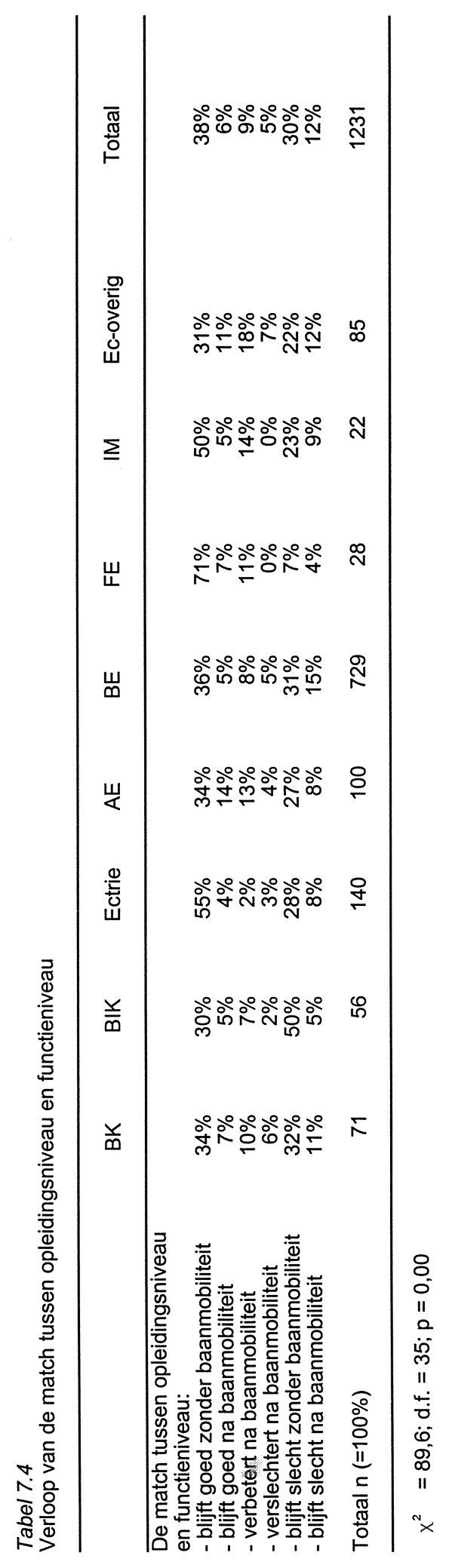


$\ldots \ldots$ 


\section{Bijlage 1 Verklarende variabelen}

Geslacht: man

Leeftijd

HO-vooropleiding

Bestuurlijke ervaring

Relevante werkervaring

Stage-ervaring

Opleidingsrichting:

- BK

- BIK

- Econometrie

$-A E$

$-B E$

$-F E$

$-I M$

- Economie-overig

$N$ maanden afgestudeerd

Directe intrede dummy = 1 indien respondent man is.

leeftijd in jaren op het moment van afstuderen.

dummy = 1 indien respondent eerder een HBO- of WO-opleiding heeft voltooid.

dummy = 1 indien respondent vóór of tijdens de opleiding bestuurlijke ervaring heeft opgedaan.

dummy = 1 indien respondent vóór of tijdens de opleiding voor het vakgebied relevante (on)betaalde werkervaring heeft opgedaan.

dummy = 1 indien respondent tijdens de opleiding stage heeft gelopen.

dummy = 1 indien bedrijfskunde;

dummy = 1 indien bestuurlijke informatiekunde;

dummy = 1 indien econometrie;

dummy $=0$ indien algemene economie

(referentiecategorie)

dummy = 1 indien bedrijfseconomie;

dummy = 1 indien fiscale economie;

dummy = 1 indien internationaal magement;

dummy = 1 indien andere economische opleidingsrichting, vrij doctoraaltracé economie, economie niet nader aangeduid of onbekend.

Aantal maanden tussen afstudeermaand en enquêtemaand.

dummy = 1 indien respondent na afstuderen niet of in totaal hooguit 3 maanden werkloos is geweest. 
Match opleidingsniveaufunctieniveau:

- goed zonder mobiliteit

- blijft goed na mobiliteit

- verbetert na mobiliteit

- verslechtert na mobiliteit

- slecht zonder mobiliteit

- blijft slecht na mobiliteit

$N$ maanden in baan

Werkregio:

- Noordoost-Nederland

- West-Nederland

- Zuid-Nederland

- buitenland

- Profit-sector

- Grote organisatie dummy = 1 indien respondent nog steeds werkt in de qua niveau passende intredebaan; dummy = 1 indien respondent na verandering van baan opnieuw niveau-passend werk heeft; dummy = 1 indien respondent een intredebaan onder zijn niveau had, van baan is veranderd en thans niveau-passend werk heeft;

dummy = 1 indien respondent een intredebaan op zijn niveau had, van baan is veranderd en thans een baan onder zijn niveau heeft; dummy = 1 indien respondent nog steeds werkt in de intredebaan onder zijn niveau;

dummy $=0$ indien respondent na verandering van baan opnieuw werk onder zijn niveau heeft (referentiecategorie).

Totaal aantal maanden dat de betaald-werkende repondent op het moment van de enquête in zijn huidige baan werkzaam is.

dummy = 0 indien werkend in provincie Groningen, Friesland, Drenthe, Overijssel, Gelderland of Flevoland (referentiecategorie);

dummy = 1 indien werkend in provincie Utrecht, Noord-Holland, Zuid-Holland of Zeeland;

dummy = 1 indien werkend in provincie NoordBrabant of Limburg;

dummy = 1 indien werkend buiten Nederland.

dummy = 1 indien respondent werkt in een profitorganisatie.

dummy = 1 indien respondent werkt in een organisatie met tenminste 100 personeelsleden. 